\title{
Detrital cave sediments record late Quaternary hydrologic and climatic variability in northwestern Florida, USA
}

\author{
Tyler S. Winkler ${ }^{1,2}$, Peter J. van Hengstum ${ }^{1,2,{ }^{*}}$, Meghan C. Horgan ${ }^{2}$, Jeffrey P. Donnelly ${ }^{3}$, Joseph \\ H. Reibenspies ${ }^{4}$
}

1. Texas A\&M University, Department of Oceanography, College Station, Texas, 77842 2. Texas A\&M University at Galveston, Department of Marine Sciences, Galveston, Texas, 77554 3. Woods Hole Oceanographic Institution, Department of Geology and Geophysics, Woods Hole, Massachusetts, 02543

4. Department of Chemistry, Texas A\&M University, College Station, Texas, 77842

*Corresponding author: vanhenp@tamug.edu

\section{Abstract} regional climate and hydrologic variability. However, the basic sedimentology, mineralogy, stratigraphic variability and emplacement history of the successions in Florida's submerged caves remains poorly understood. Here we present stratigraphic, mineralogical, and elemental data on sediment cores from two phreatic cave systems in northwestern, Florida (USA), on the Dougherty Karst Plain: Hole in the Wall Cave (HITW) and Twin Cave. Water flowing through these cave represents subsurface flow in the Apalachicola River drainage basin, and the caves are located just downstream from Jackson Blue ( $1^{\text {st }}$ magnitude spring, $>2.8 \mathrm{~m}^{3} \mathrm{~s}^{-1}$ discharge). Sedimentation in these caves is dominated by three primary sedimentary styles: (i) ferromanganese deposits dominate the basal recovered stratigraphy, which pass into (ii) poorlysorted carbonate sediment, and finally into (iii) fine-grained organic matter (gyttja) deposits upsection. Resolving the emplacement history of the lower stratigraphic units was hampered by a lack of suitable material for radiocarbon dating, but the upper organic-rich deposits have a punctuated depositional history beginning in the earliest Holocene. For example, gyttja primarily accumulated in HITW and Twin Caves from $~ 5500$ to 3500 cal yrs BP, which coincides with regional evidence for water-table rise of the Upper Floridian Aquifer associated with relative sea-level rise in the Gulf of Mexico, and evidence for invigorated drainage through the Apalachicola River drainage basin. Gyttja sediments were also deposited in one of the caves during the Bølling / Allerød climate oscillation. Biologically, these results indicate that some Floridian aquatic cave (stygobitic) ecosystems have been significantly devoid of recent organic matter supply in comparison to prehistoric intervals. The pre-Holocene poorly-sorted carbonate 

sediment contains abundant Mesozoic invertebrate fossils, and likely documents a period of

37 enhanced limestone dissolution and cave formation (speleogenesis) during lower paleo water 38 levels. Further work is still required to: (a) determine whether precipitation of the

39 ferromanganese deposits is inorganically or biologically mediated, (b) temporally constrain the 40 emplacement history of primary sedimentary styles, and (c) determine the full geographic extent 41 of these sedimentary signals. However, these preliminary stratigraphic observations suggest 42 that sedimentation in the inland underwater caves of northwestern Florida is related to 43 Quaternary-scale hydrographic variability in the Apalachicola River drainage basin in response 44 to broader ocean and atmospheric forcing.

45 


\section{Introduction}

Carbonate rocks cover $\sim 12 \%$ of the ice-free global surface, and $\sim 25 \%$ of the global population is reliant upon freshwater in karst aquifers (Ford and Williams, 1989). However, there remains a poor understanding of how karst aquifers respond to external forcing over millennial timescales, and global freshwater resources are increasingly threatened by climate change and anthropogenic development. Sedimentation in flooded caves may provide a means for assessing the long-term behavior of carbonate aquifers.

In Florida, expansive carbonates were deposited during Oligocene and Eocene sea-level highstands that have since become heavily dissolved into a mature karst landscape with ubiquitous sinkholes, karst windows, and flooded cave systems. Several regional climate records (Watts, 1969; Grimm et al., 1993; Watts and Hansen, 1994; Quillen et al., 2013) and sedimentological studies (Bates, 1995; Shinn et al., 1996; Filley et al., 2001; Lane et al., 2011; Brandon et al., 2013) have been focused on Florida's sinkhole sediments, but few studies have examined the sedimentary deposits in Florida's underwater caves and sinkholes to inform regional aquifer development. Alverez Zarikian et al. (2005) used ostracodes preserved in Little Salt Spring to examine Holocene-scale development of the Upper Floridian Aquifer. Rupert (1991) examined five short push cores collected from the Wakulla Cave System that contained fine-grained carbonate mud and quartz-sand beds (Fig. 1), but resolving their emplacement history was hampered by little chronological control. Martin and Harris (1992) examined the clay mineralogy in three surface sediment samples from Peacock, Telford, and Madison Blue Springs, and Streever (1996) documented organic matter accumulation rates of up to $80 \mathrm{~g} \mathrm{~m}^{-2}$ $\mathrm{yr}^{-1}$ in Sim's Sink Cave. Additional stratigraphic studies are still required to determine the relationship between sediment in Florida's flooded caves and regional ocean and atmospheric forcing.

Here we present a stratigraphic analysis of two inland phreatic caves on the Dougherty Karst Plain in northwestern Florida (Fig. 1). The objectives of this study were to: (i) investigate how sediment mineralogy and texture varies through time, (ii) examine the subsurface stratigraphy and lateral continuity of primary sedimentary units; and (iii) investigate possible temporal relationships between sedimentation, aquifer hydrodynamics, and regional climate change. In short, we recovered ferromanganese deposits from deeper in the stratigraphic record that pass upsection into mixed carbonate sediment and organic matter deposits. Although much remains to be learned, sedimentation in these caves appears linked to water-table rise in the upper Floridian Aquifer and hydrographic development of the Apalachicola River drainage basin since the last glacial maximum. 


\subsection{Sedimentation in phreatic caves}

Research underwater cave and sinkhole sediment has significantly expanded in the last several decades from the realization that these deposits can preserve records of paleoceanography (Yamamoto et al., 2010; van Hengstum et al., 2015a), tropical cyclone variability (Lane et al., 2011; Brandon et al., 2013; Denomee et al., 2014; van Hengstum et al., 2014), long-term groundwater conditions and salinity (Teeter and Quick, 1990; Teeter, 1995; Alverez Zarikian et al., 2005; Gabriel, 2009; van Hengstum et al., 2010; Quillen et al., 2013), millennial-scale terrestrial-oceanic climatic connectivity (Grimm et al., 1993), glacial-interglacial climate oscillations (Larsen and Mangerud, 1989), vertical sea-level and water-level change (van Hengstum et al., 2011; Collins et al., 2015a), and precipitation variability (Wurster et al., 2008; Polk et al., 2013; Onac et al., 2015). However, many questions still surround their millennial scale sedimentary processes because few flooded caves have received detailed sedimentary reconstructions.

The most significant environmental parameter influencing cave sedimentation is arguably the position (elevation) of the conduit itself with respect to the water table (in the vadose versus phreatic zone). Inundation by base level due to sea-level rise controls many cave sedimentary processes, and it changes the sedimentary structures that may be generated or preserved in the stratigraphic record. As such, sedimentary deposits and structures (both primary and secondary) can be associated with phreatic versus vadose environmental conditions in the cave (Springer and Kite, 1997; Springer et al., 1997; van Hengstum et al., 2011; Fornós et al., 2014). For example, mud cracks indicate when cave pre-existing sediment has been desiccated under vadose conditions (Fornós et al., 2009; Fornós et al., 2014). Of course, inundation does not necessarily initiate sedimentation in caves, as caves are often dependant upon external sediment supplies (Fornós et al., 2014; van Hengstum et al., 2015b) or conduit geometry (Collins et al., 2015a).For example, a submarine cave at $210 \mathrm{~m}$ BSL on Johnston Island (Central Pacific) contains no sediment (Keating, 1985), and sedimentation in some Mexican (Yucatan) phreatic caves was initiated by emplacement of mangroves on the epikarst surface (Collins et al., 2015b) The spatial position of the cave system relative to the ocean can further complicate sedimentary interpretations. This is because the position of the water table in the coastal zone is linked to eustatic sea-level change (Gascoyne et al., 1979; Shinn et al., 1996; van Hengstum et al., 2011), whereas the water table is impacted by other

112 variables further inland (e.g., structural geology, lithology, hydrogeologic gradients). Lastly, not 
all caves will act as sedimentary depocenters throughout time, as conduits can naturally become 'blown-out' and devoid of sedimentation by high rates of water flow.

Most cave sedimentology has been focused in caves located in the modern vadose zone, so cave sediment has been traditionally described, and classified, as either autochthonous (in situ) or allochthonous (transported). In vadose caves, allochthonous sediments can be delivered through fluvial, aeolian, or biologic vectors (Ford and Williams, 1989; Bosch and White, 2007; White, 2007), whereas weathering products from regional geologic formations, inorganic internal cave geochemical precipitates, or products of biomineralization often provides autochthonous sediment (Onac et al., 1997; Bosch and White, 2007; White, 2007; Fornós et al., 2009; Onac et al., 2014). As research has expanded into phreatic caves, however, it has become apparent that relating sedimentary facies to specific environmental processes is important for accurate paleo environmental reconstructions.. For example, carbonate mud deposition occurs in coastal submarine caves that are circulated with the ocean (Yamamoto et al., 2010; van Hengstum et al., 2011; van Hengstum et al., 2015a), or calcite rafts precipitation only at modern and paleo-water tables (van Hengstum et al., 2011; Collins et al., 2015a).

\subsection{Floridian cave systems: lithologic, hydrogeologic and regional overview}

Florida's caves are primarily located within pre-Miocene shallow water carbonates that were primarily deposited in the Eocene (Avon Park Formation and Ocala Limestone) and Oligocene (Suwanee and Marianna Undifferentiated Limestone)(Moore, 1955; Oyen and Protell, 2001). The Avon Park formation is dolomitized peritidal carbonates (Randazzo and Zachos, 1984; Randazzo et al., 1990), the Ocala Limestone is fossiliferous and interbedded with dolostone (Cooke, 1939; 1945; Puri, 1964; Chen, 1965; White, 1970; Schmidt, 1988; Survey et al., 2001), and the Suwanee Limestone is a pale-orange calcarenitic limestone that is also highly fossiliferous (Rupert, 1988). Together, these formations comprise the highly-porous and permeable upper Floridian aquifer and control regional hydrogeology (Dufresne and Drake, 1999; Martin and Dean, 2001; Jin et al., 2014). Depending on regional thickness of the postMiocene siliciclastics, especially the Hawthorne Group, the upper Floridian aquifer can be confined, semi-confined or unconfined (Fig. 1).

Florida has three primary karst areas: the Ocala Karst District near the Suwanee River drainage Basin (Ocala limestone), the Apalachicola Delta District (Suwanee Limestone) (Rupert, 1988; Schmidt, 1988), and in the Dougherty Karst Plain District in the Apalachicola River drainage basin (combination of Ocala and Suwanee Limestone) (Spencer and Lloyd, 1999; 
Green et al., 2009) (Fig. 1). In the Suwanee River drainage basin $\left(25,800 \mathrm{~km}^{2}\right)$, the upper Floridian aquifer is confined in the north and east by the siliciclastic Hawthorn Group until its erosional edge at the Cody Scarp when the aquifer becomes unconfined (Fig. 1). This regional geologic variability provides an excellent natural laboratory to studying the relationships between hydrogeologic variability of the upper Floridian aquifer, regional karstification, and subsurface mineralization (Florea et al., 2011; Gulley et al., 2013; Brown et al., 2014). The Suwannee River has eroded an incised channel to a maximum depth of only $9 \mathrm{~m}$ below modern sea level that extends $15 \mathrm{~km}$ out from the shoreline into the Gulf of Mexico, and it has only produced a modest Holocene delta $\left(<20 \mathrm{~km}^{2}\right)$ (Wright et al., 2005). This starkly contrasts with the deep incised valley systems and deltas produced by rivers on the siliciclastic coastlines in the northwestern Gulf of Mexico (e.g., Brazos and Trinity Rivers) during the Last Glacial Maximum (Anderson et al., 2008). Gulley et al. (2013) describes how the modern surficial drainage through the lower Suwanee River drainage basin was only activated after Holocene sea-level rise forced vertical migration of the Upper Floridian aquifer into channel systems in the unconfined pre-Miocene carbonates. The upper Floridian aquifer is also unconfined in the Marianna Lowlands (Cooke, 1945), or Dougherty Karst Plain (Spencer and Lloyd, 1999), and this region is connected into the Apalachicola River drainage basin. The Apalachicola River has produced a modern bayhead delta in Apalachicola Bay that formed $\sim 8000$ years ago (Osterman et al., 2009; Twichell et al., 2010).

Two primary groups of hypotheses are generally used to describe the formation of Florida's submerged caves (Gulley et al., 2013). First, one group of hypotheses suggest that Floridian caves formed from groundwater conditions analogous to other global localities where caves are currently being formed, such as dissolution from either sinking streams (Palmer, 2007), or mixing of different water masses that allowed the mixed water to become under saturated with respect to calcite and dissolve limestone (Rhoades and Sinacori, 1941; Brinkmann and Reeder, 1994). In contrast, the second group of ideas suggests that Florida's phreatic caves formed during lower water levels during glacioeustatic regressions and associated with hydrologic conditions not analogous to present (Florea et al., 2007; Gulley et al., 2011; Gulley et al., 2013). As discussed by Gulley et al. (2013), Holocene sea-level rise, shoreline migration in the Gulf of Mexico, and concomitant base-level rise of the Upper Floridian Aquifer would have eventually submerged Florida's cave systems, activated the present highstand hydrography of the Suwanee River System and initiated deltaic formation in the Gulf of Mexico. Perhaps these linkages between Gulf of Mexico sea-level change, co-activation of modern fluvial and subsurface hydrographic systems, and mid-Holocene emplacement of 
coastal systems (e.g., bayhead deltas) addressed in the Suwanee River drainage basin are also important in the northwestern region of Florida.

\section{Study Site}

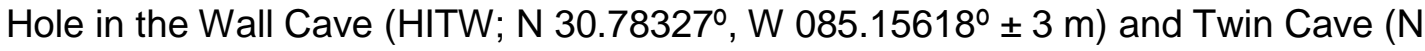
$30.78691^{\circ}, \mathrm{W} 085.14494^{\circ} \pm 3 \mathrm{~m}$ ) are located $\sim 300 \mathrm{~m}$ apart on Merritt's Mill Pond in the Marianna Karst Plain, Florida (Fig. 1, 2). Merritt's Mill Pond is a 1 surface stream feature (1.1 $\mathrm{km}^{2}$ ) that is fed at its northeastern-end by the discharge of Jackson Blue, a magnitude-1 spring with a discharge of $>2.8 \mathrm{~m}^{3} \mathrm{~s}^{-1}$ (Fig. 2). Merritt's Mill Pond has been dammed several times since the 1880s to accommodate local agricultural activities (Dodson, 2013), but it remains hydrographically part of the Apalachicola River drainage basin through smaller tributaries (e.g., Spring Creek, Chipola River). Groundwater flooding HITW Cave and Twin Cave is currently homogenized freshwater that is $\mathrm{pH}$ neutral and well oxidized. HITW Cave has a mean temperature of $20.4^{\circ} \mathrm{C} \pm 0.1$, a mean salinity of $0.15 \mathrm{psu} \pm 0.01$, a mean $\mathrm{pH}$ of $7.2 \pm 0.1$, and a mean dissolved oxygen concentration of $5.7 \mathrm{mg} / \mathrm{L} \pm 0.2$. Similarly, Twin Cave has a mean temperature of $20.3^{\circ} \mathrm{C} \pm 0.2$, a mean salinity of $0.2 \mathrm{psu} \pm 0.1$, a mean $\mathrm{pH}$ of $7.2 \pm 0.3$, and a mean dissolved oxygen concentration of $5.9 \mathrm{mg} / \mathrm{L} \pm 0.6$. The light-limited cavern area in both caves as variable and discontinuous sediment (quartz sand, coarse organic matter, freshwater mollusk shells), but this often transitions to fine-grained organic matter (gyttja) with increasing penetration into the caves.

The conduit geometry and geographic position on the stream channel differ for each cave. Twin Cave occurs in the center of Merritt's Mill Pond, and is more proximal to Jackson Blue Spring ( $1^{\text {st }}$ magnitude spring) than HITW Cave (Fig. 2). Twin Cave has a larger entrance and the conduits have a clear two-story pattern: horizontally extensive conduits occur primarily at $\sim 16 \mathrm{~m}$ and $\sim 28 \mathrm{~m}$ below the modern water table that are connected by vertical conduits or 'chimneys' In contrast, HITW Cave is located further downstream from Twin Cave (Fig. 2), it is located on the stream channel margin, and it is accessed by a narrow karst window. The conduits in HITW Cave that are proximal to the karst window have a roughly linear geometry and trend towards the northeast. The typical depth to the sediment water interface in HITW Cave is 26 to $30 \mathrm{~m}$ below the modern water level.

\section{Methods}

Sediment push cores were collected using advanced technical cave diving procedures in May 2011 and July 2014: five cores from HITW Cave and six from Twin Cave (Figs. 3, 4). Core 
depths are measured with respect to modern water table elevation $( \pm 0.3 \mathrm{~m})$, and no attempt was made to reference the current inland water table elevation to present sea level in the Gulf of Mexico. Sediment cores were collected using 5 or $8 \mathrm{~cm}$ diameter and $2.4 \mathrm{~m}$ length clear polycarbonate pipes, while following safety protocols exceeding those outlined by the American Academic of Underwater Sciences (AAUS). Coring sites were separated by approximately $60 \mathrm{~m}$ of horizontal cave passage at water depths ranging from 15 to $30 \mathrm{~m}$ below the modern water table. Thick sediment (>2.4 m) has accumulated in the surveyed areas of HITM Cave, but sediment accumulation was more limited in Twin Cave as bedrock was reached on all coring drives except TWIN-C1 (Table 1, Fig. 3)..After extraction, cores were transported back to the laboratory where they were split lengthwise, photographed, stratigraphically described according to texture and the 2009 Year (revised 2012) Munsell Soil Color Book, and continuously stored at $4^{\circ} \mathrm{C}$.

Textural variability was analyzed in all cores using a modified loss on ignition procedure (Sieve-First LOI) and laser particle size determination. For Sieve-First LOI, contiguous sediment subsamples $\left(2.5 \mathrm{~cm}^{3}\right)$ were wet sieved over a $63-\mu \mathrm{m}$ mesh and emptied into pre-weighed ceramic crucibles, and dried in an oven $80^{\circ} \mathrm{C}$ for 12 hours or until dry. After samples were dried and re-weighed, the remaining organic matter in the samples was ignited in a muffle furnace at $550^{\circ} \mathrm{C}$ for 4.5 hours. Each crucible and remaining sediment residue was then re-weighed to determine a final mass in milligrams of coarse sedimentary particles exceeding $63 \mu \mathrm{m}$ in diameter per unit $\mathrm{cm}^{3}$ (note: expressed throughout as $D_{>63 u m} \mathrm{mg} \mathrm{cm}^{-3}$, which is not density). To determine bulk organic matter a separate set of sediment samples were exposed to a classic loss on ignition procedure, following standard methods (Dean, 1974; Heiri et al., 2001). However, it is likely that organic matter is overestimated in sedimentary units rich in oxide and hydroxide minerals (Boyle, 2004). Textural variability was further quantified in HITW-C1 with a Malvern Mastersizer 2000 laser diffraction particle size analyzer to measure standard particle size statistics (volumetric mean, standard deviation, mode). The resultant particle size distributions were interpolated and displayed using a color surface plot (Fig. 5).

The mineralogy and trace element variability was examined with XRF core scanning and X-ray Diffraction (XRD). All recovered sedimentary units are represented in HITW-C1, so this core was scanned on a non-destructive Itrax core scanner every $250 \mu \mathrm{m}$ to obtain relative X-ray fluorescence measurements of the sediment's elemental composition. A further 19 sediment sub-samples from specific sedimentary units were selected for XRD analysis (HITW-C1, C2; TWIN-C1, C4, C5, C6). XRD data was measured on a Bruker-AXS D8 Advanced BraggBrentano X-ray Powder Diffractometer employing standard XRD laboratory protocols. The 
minerals in each sample were determined by comparing resultant diffractograms with the 2005 International Center for Diffraction Data (ICDD) material identification database (Fawcett et al., 2005).

Age control was established by radiocarbon dating organic matter remains with accelerator mass spectrometry. Samples of bulk organic matter were submitted for radiocarbon dataing because discernable plant macrofossils (e.g., twigs, leaves) were only present in the cores directly adjacent to the subaerial cave opening (karst windows). We assume the primary source of allochthonous organic matter in the cave is the adjacent terrestrial surface. Nine bulk organic matter samples from TWIN-C1, TWIN-C4, HITW-C1, and HITW-C2 and a twig from TWIN-C3 were submitted to National Ocean Sciences Accelerator Mass Spectrometry. Final conventional radiocarbon dates were calibrated to calendar years before present (cal yrs BP) with IntCal13 (Reimer et al., 2013) using the freeware program CALIB 7.1 to account for secular changes in atmospheric radiocarbon concentrations (Table 3).

\section{Sedimentary units}

\subsection{Organic matter deposit (Unit 1)}

Unit 1 in both caves is dominated by bulk organic matter ( $30 \pm 11 \%, n=424)$ that is 'black' (10YR 2/1) with occasional 'brownish yellow' (10YR 6/8) laminations. This facies in HITW-C1 $(0-37 \mathrm{~cm})$ is dominated by coarse to medium silt with a mean particle size of $55 \pm 14$ $\mu \mathrm{m}(4-5 \phi)$ (Table 2; Fig. 5), and the average coarse particle content for the facies $\left(D_{<63}\right.$ um $)$ was $8 \pm 9 \mathrm{mg} \mathrm{cm}^{-3}(n=340)$. Coarser-grained horizons were occasionally present (e.g., 35 to $36 \mathrm{~cm}$ in HITW-C2) that contained marine invertebrate fossils (e.g., echinoid spines, marine foraminifera) that eroded out from the host limestone bedrock. The unit generally contains low abundance of Fe and Mn (HITW-C1 XRF results), but narrow increases in Mn correlate to narrow 'brownish yellow' (10YR 6/8) laminations (e.g., 26 to $37 \mathrm{~cm}$, HITW-C1). A 'yellowish red' (5YR 4/6) horizon (<3 cm) occurred near the sediment water interface in all HITW Cave cores, (Fig. 4), which XRD results from HITW-C4 $(3-4 \mathrm{~cm})$ indicated is from the presence of goethite $\left(\mathrm{Fe}_{3}(\mathrm{O}) \mathrm{OH}\right)$ and birnessite $\left(\left(\mathrm{Na}_{0.3} \mathrm{Ca}_{0.1} \mathrm{~K}_{0.1}\right)(\mathrm{Mn})_{2} \mathrm{O}_{4}\right)$ (Fig. 7).

The lateral continuity and net accumulation of Unit 1 differed between each cave. The uppermost $35-75 \mathrm{~cm}$ of sediment in all cores from HITW Cave contained a texturally similar unit 1. In contrast, unit 1 in Twin Cave was primarily fine-grained (gyttja), except near the karst window (TWIN-C3) where coarse-grained organic fragments dominated with occasional freshwater gastropod shells (Figs. 4, 5). More distally into TWIN Cave, Unit 1 attenuated into a thin layer $(<5 \mathrm{~cm})$ that was texturally similar to HITW Cave. Lastly, TWIN-C1 was obtained from 
the base of vertical shaft connecting the upper and lower horizontal conduit levels. Unit 1 occurred as a thin deposit at top of TWIN-C1 $(<5 \mathrm{~cm})$, but also as thick sequence from 22 to 65 cm depth (Fig. 4). This lower deposit contained more intact and leafy organic matter particles in an overall fine-grained organic matter matrix.

\subsection{Carbonate sediments (Unit 2)}

This facies is present in both HITW Cave and Twin Cave, and is dominated by poorlysorted carbonate particles with low bulk organic matter content $(4 \% \pm 3 \%$ bulk organic matter, $n$ $=442$ ). The facies was sub-divided because of its heterogeneous texture (Units $2 \mathrm{~A}$ and $2 \mathrm{~B}$, Figs. 4-6). Unit 2A can range from 'yellow' (10YR 8/6) to 'strong brown' (7.5YR 4/6), and Unit 2B is 'very pale brown' (10YR 8/3) to 'brownish yellow' (10YR 6/8). Based on particle size analysis of HITW-C1, Unit 2A contains intervals of fine-grained sandy-silt (4 to $8 \phi$ ) with a mean particle size of $53 \pm 19 \mu \mathrm{m}$ ( $n=11,38$ to $49 \mathrm{~cm}$ :) whereas Unit $2 \mathrm{~B}$ is fine to medium sand ( 0 to $3 \phi)$ with a mean particle size of $292 \pm 111 \mu \mathrm{m}(n=12,49$ to $60 \mathrm{~cm})$. The coarser sediment particles in Unit 2B are typically lithified marine fossils (e.g., echinoid spines, ichthyoid tooth) and carbonate rock particles. The sieve-first LOI technique that examined the coarse fraction also indicates the textural heterogeneity of Unit 2 , as the coarse sediment fraction $\left(D_{>63 \mu \mathrm{m}}\right)$ varied between 16 and $118 \mathrm{mg} \mathrm{cm}^{-3}$ (mean: $73 \pm 28 \mathrm{mg} \mathrm{cm}^{-3}, n=116$ ) in Unit $2 \mathrm{~A}$ and from 120 to $993 \mathrm{mg} \mathrm{cm}^{-3}$ (mean: $\left.350 \pm 191 \mathrm{mg} \mathrm{cm}^{-3}, n=326\right)$ in Unit $2 \mathrm{~B}$.

XRF elemental analysis indicates a high abundance of $\mathrm{Ca}$ and $\mathrm{Sr}$ in Unit 2, with a low abundance of Fe and Mn (Fig. 5). XRD analysis of samples from Unit 2 indicate that calcite $\left(\mathrm{CaCO}_{3}\right)$ and quartz $\left(\mathrm{SiO}_{2}\right)$ were the most dominant minerals, which supports the XRF results (Table 2; Figs. 5, 7). However, goethite $\left(\mathrm{Fe}_{3}(\mathrm{O}) \mathrm{OH}\right)$, magnetite $\left(\mathrm{Fe}_{3} \mathrm{O}_{4}\right)$, and trace amounts of kaolinite $\left(\mathrm{Al}_{2} \mathrm{Si}_{2} \mathrm{O}_{5}(\mathrm{OH})_{4}\right)$ were also detected (Table 2; Fig. 7),. No evidence of desiccation was observed (e.g., mudcracks).

\subsection{Fine-grained iron-rich facies (Unit 3)}

Unit 3 is a laminated Fe-rich (Fig. 5) unit that contains an average of $\sim 9 \% \pm 2 \%$ bulk organic matter, but this is likely an over estimate given the high content of oxide minerals (Boyle, 2004). The negligible Mn content in Unit 3 differentiates it from Unit 4. In general, unit 3 is dominated by silt and clay particles (mean particle size: $9 \pm 3 \mu \mathrm{m}, 6$ to $10 \phi, n=28$ ) with coarser-grained sand horizons. So, we further sun-divided Unit 3 into subunits based on the content of coarse particles (Figs. 4-6). Subunit 3A contained a mean coarse sediment fraction $\left(D_{>63 \mu \mathrm{m}}\right)$ of $\sim 23 \pm 16 \mathrm{mg} \mathrm{cm}^{-3}(n=46)$, but Unit 3B had a mean coarse sediment fraction of $\sim 101$ 
$317 \pm 41 \mathrm{mg} \mathrm{cm}^{-3}$ ( $n=29$ ) (Figs. 4-6). No evidence of desiccation was observed in this unit (e.g.,

318 induration crusts, mudcracks). Based on XRD analyses on a sample of Unit 3 from HITW-C1,

319 the minerals goethite $\left(\mathrm{Fe}_{3}(\mathrm{O}) \mathrm{OH}\right)$, magnetite $\left(\mathrm{Fe}_{3} \mathrm{O}_{4}\right)$, calcite $\left(\mathrm{CaCO}_{3}\right)$, and quartz $\left(\mathrm{SiO}_{2}\right)$ were

320 present (Fig. 7). It is noteworth that visually 'Yellow' (10YR 7/8) laminations in the sediment

321 appear to correlate with increased levels of Ca content in HITW-C1, and 'dark brown' (7.5YR

322 2.5/3) laminations \appear to correlate to increased Mn content.

\subsection{Intercalated Mn- and Fe-oxides (Unit 4)}

Only HITW Cave cores contain the laminated Unit 4, which has higher Mn content than the other units (Fig. 5) and is laminated (Fig. 4). Bulk organic matter content is estimated at $8 \%$ $\pm 2 \%(n=135)$, but this is likely an overestimate based on the high content of ferromanganese minerals. One layer dominated by Mn in Unit 4 was exceptionally dark in color ('dark brown', 7.5YR 2.5/2), which, could be correlated between several cores in HITW Cave (e.g., HITW-C1: 132-142 cm, HITW-C2: 90-101 cm, HITW-C4: 134-150 cm). Large accumulations of Mndominated cave sediments have been previously documented, such as the $3 \mathrm{~m}$ successions of manganese oxide sediments in the lowest conduit levels in Jewel Cave, South Dakota (Hill, 1982; Peck, 1986). Unit 4 is also divided into subunits based on the textural variability. Unit 4A contains well-sorted fine to coarse silt ( 8 to $4 \phi$, Unit 4A), but Unit 4B contains medium to coarse sand layers (2 to $0 \phi$ ) with invertebrate fossil grains and carbonate sand particles (Figs. 4-6).

Though the precise mineralogical structure of naturally precipitated Mn oxides and oxyhydroxides can be difficult to determine due to their extreme microcrystallinity (Lind et al., 1987; Davison, 1993), the intensity of the correlated peaks in the XRD diffractograms would suggest that birnessite $\left(\left(\mathrm{Na}_{0.3} \mathrm{Ca}_{0.1} \mathrm{~K}_{0.1}\right)(\mathrm{Mn})_{2} \mathrm{O}_{4}\right)$, jacobsite $\left(\mathrm{MnFe}_{2} \mathrm{O}_{4}\right)$ and ramsdellite $\left(\mathrm{MnO}_{2}\right)$ dominate Unit 4 (Table 1, Figs. 6, 7). XRD results indicate that goethite $\left(\mathrm{Fe}_{3}(\mathrm{O}) \mathrm{OH}\right)$, calcite $\left(\mathrm{CaCO}_{3}\right)$, and quartz $\left(\mathrm{SiO}_{2}\right)($ Table 2; Fig. 7) are also present. Similarly to Unit 3, XRF scans of HITW-C1 reveal alternating 'yellow' (10YR 7/8) and 'black' (10YR 2/1) fine-grained laminations throughout most of Unit 4 sediments that correlate to increased levels of $\mathrm{Ca}$ in the sediment (Fig. 5).

\subsection{Ferromanganese-rich sandy carbonate mud (Unit 5)}

Unit 5 only occurs in TWIN Cave (TWIN-C1, C4, C5, and C6) and it is highly heterogeneous in terms of coarse sediment $(>63 \mu \mathrm{m})$ and mineralogy. It would visually appear to be variant of Unit 2 (carbonate sediment), but it contains additional layers that are rich in ferromagnesian minerals. This fact is reflected in the sediment color, which was 'dark reddish 
brown' (5YR 3/4) with occasional 'dark brown' (7.5YR 2.5/2) laminations, or vice versa. The particle size in Unit 5 varies from clay to coarse sand (10 to $0 \phi$ ), so the unit was further divided into subunits (Units $5 A$ and $5 B$ ) based on bimodal distribution of coarse sediment fraction $\left(D_{>63}\right.$ $\mu \mathrm{m}$ ) data. Unit $5 \mathrm{~A}$ is dominated by silts and clays with a mean coarse sediment fraction of $64 \pm$ $21 \mathrm{mg} \mathrm{cm}^{-3}(n=30)$, whereas Unit 5B is comprised of fine to medium sand with a mean coarse sediment fraction of $214 \pm 101 \mathrm{mg} \mathrm{cm}^{-3}(n=17)$. Organic matter content in both subunits was generally very low with a mean composition of $3 \pm 2 \%(n=46)$ (Table 2; Fig. 5).

The results of the XRD analysis indicate an inconsistent trace metal and mineralogical characteristics for this unit. Overall, crystalline minerals such as calcite $\left(\mathrm{CaCO}_{3}\right)$ and quartz $\left(\mathrm{SiO}_{2}\right)$ appear to be the most dominant; however, there is also a very strong presence of Fe and Mn oxides and oxyhydroxide minerals including goethite $\left(\mathrm{Fe}_{3}(\mathrm{O}) \mathrm{OH}\right)$, magnetite $\left(\mathrm{Fe}_{3} \mathrm{O}_{4}\right)$, birnessite $\left(\left(\mathrm{Na}_{0.3} \mathrm{Ca}_{0.1} \mathrm{~K}_{0.1}\right)(\mathrm{Mn})_{2} \mathrm{O}_{4}\right)$, jacobsite $\left(\mathrm{MnFe}_{2} \mathrm{O}_{4}\right)$, and ramsdellite $\left(\mathrm{MnO}_{2}\right)$ as well as trace amounts of kaolinite $\left(\mathrm{Al}_{2} \mathrm{Si}_{2} \mathrm{O}_{5}(\mathrm{OH})_{4}\right)$ (Fig. 7). In fact, this facies contains discernable levels of every mineral identified in each of the other facies identified in Units 2-4.

\subsection{Quartz sand (Unit 6)}

Unit 6 is a well sorted, 'white' quartz sand (10YR 8/1). This facies is only present in TWIN-C2 at 49 to $54 \mathrm{~cm}$, just before the onset of the deposition of gyttja from Unit 1. Sediment from this unit were too coarse to be analyzed using XRD methods; however, exposure of the sand-sized particles to $10 \% \mathrm{HCl}$ produced no effervescence, which suggests the sand is most likely quartz $\left(\mathrm{SiO}_{2}\right)$. This unit also contained little organic matter $(>1 \pm 1 \%)$, and had the highest mean coarse sediment $(>63 \mu \mathrm{m})$ fraction of all of the observed facies $\left(1074 \pm 59 \mathrm{mg} \mathrm{cm}^{-3}\right)$ (Table 2; Fig. 4). No fossil material was present.

\section{Chronology and correlation}

Based on the textural and mineralogical characteristics, the facies can be grouped into three broad categories of sedimentary style, in stratigraphic order from bottom to top: ferromanganese deposits (Units 3, 4), carbonate sediment (Unit 2), and organic matter deposits (Unit 1). Aside from the bulk organic matter deposit (Unit 1), there was no substantial organic material in Units 2-6 for radiocarbon dating (i.e., terrestrial plant macrofossils, reliable bulk organic matter), which hampered a direct interpretation for the timing of their emplacement. However, they must have been emplaced during the late Pleistocene given the oldest radiocarbon dates obtained from TWIN-C1 (Table 3). 
Based on the longer cores from HITW Cave, the basal and presumably oldest facies are the ferromanganese deposits. The recovered stratigraphy from Twin Cave is missing the thick ferromanganese deposits that are present in HITW Cave, but this may be an artifact of the research design since there are many conduits in Twin Cave that were not sampled. The ferromanganese deposits can be correlated between the cores collected from HITW cave, and are likely derived from a similar environmental emplacement mechanism given their similar character. Indeed, dating the transition between the ferromanganese deposits and carbonate sediment is critical to resolving uncertainty regarding its emplacement history, but nevertheless, this salient sedimentary contact warrants correlation in the subsurface.

In HITW Cave, the ferromanganese deposits pass upwards into carbonate sediments, which were also present in the subsurface of Twin Cave. The presence of carbonate sedimentary units with similar sedimentary character warrants correlation in the subsurface, but the subunits in Unit 2 (Unit 2A versus 2B) could not be confidently correlated between core sites (Fig. 4). Perhaps the subtle textural variability between Unit $2 \mathrm{~A}$ and Unit $2 \mathrm{~B}$ is related to subtle site-specific depositional processes in the conduit from local hydrodynamics or entirely stochastic processes. In HITW Cave, the carbonate sediments pass into the organic deposits at $\sim 5500$ cal yr BP, which suggests a marked change in environmental processes operating the cave. There are no shallower conduit levels in HITW Cave, which suggests that sedimentary processes deeper in the aquifer abruptly changed from those that were promoting carbonate dissolution to a régime dominated by allochthanous organic matter sedimentation.

In Twin Cave, however, sedimentation alternated between the carbonate sediment and organic matter deposits (e.g., TWIN-C1, Fig. 4), which suggests an alternation of environmental processes (carbonate dissolution vs. allochthonous organic matter supply). This is likely a combination of conduit geometry and elevation. Most sediment cores from Twin Cave are from a shallower conduit level than HITW Cave, and therefore the sediment cores are documenting activity at a shallower level in the aquifer. The vertical chimneys between the upper and lower conduit levels can also permit remobilization of sediment from the upper conduit levels to the lower conduit levels. In the other cores from the shallower sites in Twin Cave (TWIN-C6, C4, 5),

412 there is a final transition to Unit 5, which appears to be a combination of carbonate and 413 ferromanganese sediment. The alternation between carbonate sediments with Cenozoic fossils 414 and recent organic matter deposits in the shallower conduits levels in Twin Cave suggest an 415 alternating environmental processes. However, the organic matter deposits are temporally 416 constrained with radiocarbon dates, so the prominent organic matter deposits are correlated in 417 the subsurface. 
Based on the radiocarbon results, the organic matter deposits were emplaced during two pulses that we term Organic Matter Pulse 1 and 2. Organic Matter Pulse 1 (OMP-1) occurred from 13,900 to $12,700 \mathrm{cal}$ yr BP, which deposited organic matter in both the upper and lower conduit level in Twin Cave. Unit 1 accumulated in the lower conduit levels at TWIN-C1 from $13,950 \pm 160$ to $13,930 \pm 190$ cal yr BP, but was deposited for a longer period of time until $12,762 \pm 80 \mathrm{cal} \mathrm{yr} \mathrm{BP}$ at the shallower conduit levels (date from TWIN-C4 at 26 to $58 \mathrm{~cm}$ ). Above OMP-1 in TWIN-C4 is a layer of carbonate sediments, similar to TWIN-C1 from 22 to 65 $\mathrm{cm}$, in TWIN-C4 from 26 to $58 \mathrm{~cm}$, in TWIN-C6 from 21 to $40 \mathrm{~cm}$, and in TWIN-C2 from 38 to 48 $\mathrm{cm}$. Therefore, we correlate this lower organic matter deposit in the subsurface of the Twin Cave cores, but recognize that uncertainty in this correlation remains until further radiocarbon dating is obtained. No Unit 1 accumulated at the TWIN-C5 sampling location, but given the vertical conduit ('vertical chimney') connecting the upper and lower horizontal conduit levels before the TWIN-C5 core site, it is likely that sediment bypassed the site of TWIN-C5 by instead becoming transported down the Skiles Passage or a vertical chimney ('sediment bypass', Fig. 3). If correct, this would indicate that conduit morphology is an important control on sedimentation in inland flooded caves (Fig. 3), which has also been documented for coastal phreatic caves (Collins et al., 2015a).

Organic Matter Pulse-2 (OMP-2) occurred from 5600 to 3500 cal yr BP, and is represented by Unit 1 deposits in both Twin and HITW Cave. A thin deposit of unit 1 does occur at the top of TWIN-C1 $(0-5 \mathrm{~cm})$, with constraining ages at 0 to $1 \mathrm{~cm}$ and 4.5 to $5.5 \mathrm{~cm}$ providing ages of $5170 \pm 130$ and $3920 \pm 50$ cal yr BP, respectively. This age inversion may be related to local bioturbation (e.g., cat fish), or it could be related to sediment from the upper conduit level becoming eroded since its initial deposition and becoming re-mobilized into the lower conduit level down the vertical chimney. However, the inverted ages still indicate that organic matter influxed into Twin Cave occurred during a discrete time window, it just has since experienced some re-mobilization. Closer to the cave exit, the dated twig from Unit 1 in TWIN-C3 at $32.5 \mathrm{~cm}$ was aged to $7500 \pm 60 \mathrm{cal}$ yr BP, suggesting that deposition of Unit 1 at this core site was dependent upon its proximal location to the karst window (Fig. 3b). OMP-2 is more expanded in HITW Cave, with a 35 to $75 \mathrm{~cm}$ thick deposit at the tops of all HITW Cave cores. Based on the radiocarbon results from HITW-C1 $(35-36 \mathrm{~cm})$ and in HITW-C2 $(34-35 \mathrm{~cm})$, Unit 1 began deposition at $5630 \pm 30$ and $5530 \pm 60$ cal yrs BP, respectively (Table 2). Most importantly, these results promote three inferences: (1) that modern sedimentation is negligible in the distal conduits of both caves, (2) that OMP-2 occurred over 2100 years from 5600 to 3500 cal yrs BP, and (3) OMP-2 deposited more sediment into HITW Cave than Twin Cave. 


\section{Discussion}

\subsection{Emplacement of ferromanganese deposits}

Iron and manganese oxides and oxyhydroxide minerals dominate the basal sediments recovered from HITW Cave (Units 3-5), which can be more generally referred to as ferromanganese deposits (Ghiorse and Ehlich, 1992; Splide et al., 2006; Gázquez et al., 2011). Thinner horizons of ferromagnesian deposits are also intercalated in Unit 5 which forms the most recently deposited sediments in Twin Cave. However, the emplacement of these upper horizons in Unit 5 likely occurred under different environmental conditions than the basal ferromagnesian deposits in HITW Cave based on the radiocarbon results (discussed further below), and their texture and mineralogy (see section 4.5).

The oxidation of $\mathrm{Mn}(\mathrm{II})$ and $\mathrm{Fe}(\mathrm{II})$ into solid oxide precipitates can occur inorganically, when the oxygen content or $\mathrm{pH}$ of water is increased and enables the precipitation of metal oxides. In caves, a redox gradient can naturally develop across the aquifer-cave boundary as anoxic aquifer waters rich in $\mathrm{Mn}(\mathrm{II})$ and $\mathrm{Fe}(\mathrm{II})$ ions drain into oxygenated cave systems and form insoluble Fe(III) and Mn(III,IV) precipitates (de Vitre and Davison, 1993; Martin, 2005; Frierdich and Catalano, 2012; Brown et al., 2014). As such, it has been suggested that thick successions of ferromanganese deposits in Cova des Pas de Vallgornera, Mallorca, were produced inorganically from the oxidization of upwelling (hypogene) groundwater (Fornós et al., 2014).

However, ferromanganese deposits can also be biologically precipitated by Fe- and Mnoxidizing bacteria (e.g., Leptothrix, Sphaerotilus, Clonothrix, Thiotrix, Hyphomicrobumn) in oxygenated waters with a near-neutral pH (Peck, 1986). Microbes living in caves can even produce expansive ferromanganese stromatolites (Rossi et al., 2010; Lazano and Rossi, 2012). Biogenic ferromanganese crusts have been identified on cave surfaces, where $\mathrm{Mn}$ and Fe is derived from the chemical weathering of the host bedrock (Northup et al., 2003; Spilde et al., 2006; Carmichael et al., 2013). Ferromanganese deposits can also form in freshwater streams flowing through caves and produce ferromanganese crusts (White et al., 2009), shallow sedimentary deposits (Onac et al., 1997; Manolache and Onac, 2000), or pebbles and coatings on pebbles (Frierdich and Catalano, 2012).

In an important example from Florida, Florea et al. (2011) describe the active flocculation

482 and precipitation of iron oxides in Thornton's Cave by Leptothrix (Withlacoochee River drainage 483 basin; Fig. 1). Depending upon the season, Thornton's Cave functions as either a sink (siphon) 484 or spring (estavelle) with the adjacent Withlacoochee River (Fig. 1), The local water table is 485 positioned within the conduits of Thornton's Cave, and the elevation of the water table oscillates 
with the seasons (Florea et al., 2011). If we assume that the overall stratigraphic architecture in HITW Cave is organized from oldest to youngest, then a minimum age for the basal ferromanganese deposits is the late Pleistocene, and the basal deposits would likely be coincident with periods of lower aquifer water levels during lower eustatic sea levels (Florea et al., 2007). It is possible that Thornton's Cave provides a modern analog for paleo environmental conditions when the ferromanganese deposits were emplaced in HITW and Twin Cave. No evidence of desiccation or induration was observed in our cores like has been observed in Mallorcan cave sediments (Fornós et al., 2009), which suggests very humid conditions or intermittent standing water in the cave (likely not vadose conditions). Additional modern sedimentary analogs are required to better understand environmental conditions in the cave during deposition of the ferromanganese deposits.

At this stage it is uncertain whether inorganic or biologic processes drove precipitation of the ferromanganese deposits, or specifically how these processes relate to the paleo water table (vadose zone, phreatic zone, or at the water table). The presence of coarse horizons of Miocene fossils within the ferromanganese deposits also suggests some occasional increased water movement and/or calcite dissolution. However, the preservation of fine laminations throughout Units 3-5 suggests that quiescent water conditions were most prevalent. Lower eustatic sea level during the late Pleistocene likely placed the local water table considerably closer or below the basal conduit level of HITW Cave (Florea et al., 2007), which certainly altered regional subsurface hydrography. At this stage, it would be speculative to provide a specific elevation of the paleo table during the Pleistocene, as the water table elevation inland is complex. However, such prehistoric water levels perhaps generated a hydrographic system in HITW Cave at least partially analogous to modern conditions in Thornton's Cave. Such a scenario would also explain the absence of thick ferromanganese deposits in the horizontal conduits at a shallower level in the subsurface in Twin Cave (Fig. 3B), which may have been completely in the vadose zone during contemporaneous deposition of Units 3 and 4 in HITW

512 Cave. Alternatively, the absence of thick ferromanganese deposits in Twin Cave at the

513 shallower conduit levels may give credibility to a hypogene source of trace metals for deposition

514 in HITW Cave, since Twin Cave would have provided a thoroughfare of terrestrially-sourced 515 water (epigene) to the paleo water table of the upper Floridian Aquifer. Further geochemical 516 research is required to determine the origin and emplacement history of the ferromanganese 517 deposits.

\subsection{Enhanced dissolution and carbonate sedimentation}


Another primary sedimentary style in both caves is the carbonate sediments (Unit 2),

which suggests a similar environmental process impacted both caves. Unfortunately, the timing for the emplacement of the carbonate sediments is poorly understood because of a lack of suitable material for radiocarbon dating in these sedimentary units. However, the radiocarbon ages at the contact with Unit 1 in both Twin Cave (TWIN-C4) and in HITW Cave (HITW-C1,C2) indicate emplacement at least from the early to middle Holocene, and the core logs indicate that deposition typically occurs after deposition of the ferromanganese deposits. It is striking that carbonate sedimentation in HITW Cave terminated in the mid-Holocene. This suggests that the environmental conditions required for enhanced carbonate dissolution are dynamic, and not constant in geologic time or geographic space.

Based on the abundance of marine invertebrate fossil remains (e.g., shark teeth, echinoid spines), these sediments likely evidence periods of enhanced bedrock dissolution and conduit expansion during lower paleo-water tables. Florea et al. (2007) noted the prevalence of cave passages in west-central Florida at 12-15 m above modern sea level and $35 \mathrm{~m}$ below the modern water table, and suggested their prevalence was associated with enhanced dissolution at specific paleo water tables during previous sea level lowstands. Recently, Gulley et al. (2015) describe how heterogeneous $\mathrm{pCO}_{2}$ concentrations in freshwater meteoric lenses is likely contributing to dissolution of Florida's caves, a process that is amplified when terrestrial water flows into a subsurface cave (Gulley et al., 2011). In the modern environment, Brown et al. (2014) documented enhanced calcite dissolution and ferromanganese deposition in Madison Blue Cave System (Suwanee River drainage basin) caused by river reversals during storms. Madison Blue usually functions as a spring and discharges water into the Santa Fe River, but intense precipitation causes river water to instead to flush into the cave (siphon) and push groundwater into the aquifer matrix porosity, which promotes calcite dissolution and trace metal sorption from the bedrock. As storm levels recede, reduced water from the aquifer matrix porosity re-enters conduits with oxygenated cave water to precipitate metal oxides on cave walls. However, Gulley et al. (2013) suggested that river reversals alone are not responsible for generated Florida's phreatic caves as there would be little way to force floodwater below a water table level without a pre-existing void. Given the large successions of pre-Holocene carbonate sedimentation in HITW and TWIN Caves, the suggestion of Gulley et al. (2013) seems valid. In fact, the carbonate sedimentation concurs with the hypothesis of Gulley et al. (2013) and Florea et al. (2007) that enhanced dissolution most likely occurs at paleo water tables. However, stratigraphic analysis of sediments emplaced in phreatic caves in eastern Floridian is needed to further evaluate this hypothesis. 


\subsection{Organic matter deposition and linkage to the Apalachicola River Drainage Basin}

Deposition of Unit 1 appears closely linked to known intervals of climate change and

The deposition of Organic Matter Pulse 1 (OMP-1) in Twin Cave from 13,900 to 12,700 cal yr BP coincides with the Bølling / Allerød climate oscillation, which is a period of general global climate warming that terminated with a return to cold, glacial-like climate conditions at the onset of the Younger Dryas at 12,700 yr BP (Bard et al., 2010; Deschamps et al., 2012) (Fig. 8). The lack of OMP-1 in HITW Cave suggests that either (a) the HITW karst window was not yet open, or (b) the surficial stream in Merritt's Mill Pond that was transporting organics into Twin Cave was not interacting with the karst window on the side of the stream channel that is the entrance to HITW Cave. Based on pollen reconstructions from Camel Lake (Watts et al., 1992) and Sheelar Lake (Watts, 1980), northern Florida was dominated by mesic, temperate forests through the Bølling / Allerød Interstadial which would indicate that the precipitation was high (Overpeck et al., 1989) (Figs. 1, 8), but spruce populations near Camel Lake from 14,330 \pm $275 \mathrm{cal}$ yr BP to $12,610 \pm 135 \mathrm{cal}$ yr BP indicate that the lower Apalachicola basin was unusually cool at this time (Watts et al., 1992), thus behaving paradoxically to the global trend towards warmer environments during this period. It is possible that regional cooling of Northwestern Florida during the Bølling / Allerød Interstadial is related cooling of the Gulf of Mexico caused by Mississippi River discharge of glacial meltwater between 14,650 and 13,600 yr BP (Fairbanks, 1989; Bard et al., 1990; Deschamps et al., 2012) (Fig. 8), which is thought to have also rapidly changed sea level by as little as $0.66 \pm 0.07 \mathrm{~m}$ (Wickert et al., 2013) or as much as $17 \pm 5 \mathrm{~m}$ (Deschamps et al., 2012). This sea-level rise could have had a significant effect on the water table level and hydrodynamics of the upper Floridian aquifer in northwestern Florida, perhaps even promoting short-lived surface streams and ponds. Such changes in surface and groundwater hydrology could be related to deposition of OMP-1.

After deposition of OMP-1 in Twin Cave, carbonate sedimentation resumes at the upper horizontal conduit level, whereas Unit 5 (ferromanganese-rich sandy carbonate mud) is deposited in the lower conduit level (TWIN-C1, Fig. 3). In nearby Camel Lake, a depositional hiatus occurred from $\sim 10,000$ to $7000 \mathrm{yr}$ BP (Figs. 1, 8). This depositional hiatus was previously 
interpreted as related to lowering of the upper Floridian aquifer, perhaps from a combination of a lower early Holocene water table or significant regional aridity (Watts et al., 1992). If this interpretation is correct, then carbonate sediment from enhanced bedrock dissolution resumed in the upper conduit levels in Twin Cave.

Deposition of OMP-2 from 5600 to 3600 cal yr BP occurs right after evidence for the upper Floridian aquifer flooding and activating modern surficial hydrographic features (lakes, streams) in Florida, and is likely correlated with increased regional precipitation and associated discharge through the Apalachicola River drainage basin (Figs. 1, 8). Given the antecedent carbonate bedrock, it has been suggested that that many surficial hydrologic networks (i.e., lakes, streams) in Florida were initiated as early as $~ 8000 \mathrm{yr}$ BP, as sea-level forced vertical migration of the upper Floridian aquifer flooded regional topographic lows (Watts and Hansen, 1988; Gulley et al., 2014). For example, the Suwannee River only incised a valley to 9 m below sea level in the Gulf of Mexico (Wright et al. 2005), suggesting that Holocene drainage through the Suwannee River only initiated after topographic lows on the Ocala Karst Plain were inundated by sea-level-forced vertical migration upper Floridian aquifer (Fig. 1). In the Apalachicola River drainage basin, perhaps Merritt's Mill Pond was a dry basin until 6000 yr BP, but inundation by the upper Floridian Aquifer activated the surficial stream network and initiated erosion of terrestrial organic matter into HITW Cave and Twin Cave. At the coastline in Apalachicola Bay, sub-surface geophysical and sedimentary analysis indicates the onset of estuarine conditions only $\sim 6400$ yr BP (Fig. 8), when sea level in the Gulf of Mexico was $\sim 6 \mathrm{~m}$ below present (Milliken et al. 2008). More specifically, an eastern lobe of the modern Apalachicola River bayhead delta was only active from 5800 to 5100 yr BP (Osterman et al., 2009; Twichell et al., 2010), during a known increase in regional precipitation. In a review of Floridian lake level history, Watts and Hansen (1988) suggest increased swamping in northern Florida from 5000 to $2500 \mathrm{yr}$ BP was related to increased regional precipitation. Similarly, a pollen reconstruction from Goshen Springs in southern Alabama (Fig. 1) also indicates increased precipitation beginning at $\sim 5000 \mathrm{yr}$ BP (Delcourt, 1980). In southern Florida, $\delta^{18} \mathrm{O}$ ratios from ostracodes living in Little Salt Spring document increased rainfall from $~ 5700$ to 4000 yr BP (Alverez Zarikian et al., 2005). Collectively, these records suggest that deposition of OMP-1 occurred after the upper Floridian aquifer flooded topographic lows and initiated drainage through the Apalachicola River drainage basin; but also coincides with evidence for invigorated flow through the Apalachicola River drainage basin related to increased regional precipitation. 
In the topmost portion of the cores, "yellowish red" (5YR 4/6) ferromanganese mineralization is present that is either (a) a narrow deposit in HITW Cave, or (b) part of Unit 5 in Twin Cave (Figs. 4-6). Given that these sediments are likely deposited after regional base-level rise decelerated in the middle Holocene, it seems likely that the seasonal geochemical processes described at Madison Blue in the Suwanee River drainage basin by Brown et al. (2014) are also operating at Twin and HITW Caves. Alternatively, this narrow layer of ferromanganese deposits represents a redox boundary as anoxic hypogene water is oxidized when it encounters the oxygenated conduit.

\section{Conclusions}

- Late Quaternary detrital sedimentation in two phreatic caves in northwestern Florida appears broadly linked to ocean and atmospheric forcing, whereby feedbacks between sea level and the local water table elevation and regional precipitation patterns impact cave sedimentation..

- Six distinct facies were identified in the subsurface of HITW Cave and Twin Cave in Marianna, Florida, USA, which can be grouped into three broad sedimentary styles that are related to base-level variability of the upper Floridian aquifer throughout the late Quaternary. The general architecture of these primary sedimentary styles in a transgressive sequence, from bottom to top, is: ferromanganese deposits, carbonate sediments, and organic matter deposits. Lateral textural variability was also observed, as sedimentation in conduits closest to the karst window were different than deeper into the cave.

Ferromanganese deposits were likely deposited during lower base levels of the upper Floridian aquifer during the late Pleistocene. It remains uncertain if they are derived from biologic (e.g., bacterial) or inorganic (e.g., oxidation of hypogene waters) processes.

- Texturally-variable carbonate sediment that is generally Ca- and Sr-rich, and Mn- and Fepoor was also likely deposited during lower paleo water levels. The abundance of invertebrate fossils within these sediments suggests that they document periods of enhanced limestone dissolution. Based on the successions from lower conduit levels in HITW Cave, the environmental conditions necessary for enhanced dissolution and carbonate sedimentation have not occurred over the last 5600 years. However, the environmental conditions necessary for enhanced dissolution may have persisted at the shallower conduit levels of TWIN Cave until more recently (Fig. 3). 
- Organic matter deposits accumulate proximal to the cave exits (karst windows), and their pulsed deposition occurred during discrete time intervals, perhaps evidencing when invigorated flow occured through the Apalachicola River drainage basin. For example, OMP-1 ( 14000 yr BP) occurred during the Bølling / Allerød climate oscillation, and OMP2 (5600 to 3600 yr BP) occurred during an interval of increased regional precipitation in the southern USA.

- Analysis of successions from other Floridian caves is required to assess the regional continuity of these sedimentary signals, their climatic forcing, and further refine their emplacement history.

\section{Acknowledgements}

Field support was provided by M. Loyco, E. Sorenson and the staff at Cave Adventures, and technical support was provided was provided by Kathy A. Schwehr. Funding for this project was provided by The Explorer's Club Youth Activity Fund, Society for Sedimentary Geology, Texas Institute of Oceanography, the Geological Society of America, and NSF Award OCE1356509. 


\section{References}

Alverez Zarikian, C.A., Swart, P.K., Gifford, J.A., Blackwelder, P.L., 2005. Holocene paleohydrology of Little Salt Spring, Florida, based on ostracod assemblages and stable isotopes. Palaeogeography, Palaeoclimatology, Palaeoecology 225, 134-156.

Anderson, J.B., Rodriguez, A.B., Milliken, K., Taviani, M., 2008. The Holocene evolution of the Galveston estuary complex, Texas: Evidence for rapid change in estuarine environments. Geological Society of America Special Papers 443, 89-104.

Bard, E., Hamelin, B., Delanghe-Sabatier, D., 2010. Deglacial meltwater pulse 1B and Younger Dryas sea levels revisted with boreholes at Tahiti. Science 327, 1235-1237.

Bard, E., Hamelin, B., Fairbanks, R.G., 1990. U-Th ages obtained by mass spectrometry in corals from Barbados: sea level during the past 130, 000 years. Nature 346, 456-458.

Bates, A.L., Spiker, E.C., Hatcher, P.G., Stout, S.A., Weintraub, V.C., 1995. Sulfer geochemistry of organic rich sediments from Mud Lake, Florida, USA. Chemical Geology 121, 245-262.

Bosch, R.F., White, B., 2007. Lithofacies and transport of clastic sediments in karstic aquifers. In: I.D. Sasowsky, J. Mylroie (Eds.), Studies of Cave Sediments: Physical and Chemical Records of Paleoclimate. Springer US, New York City, NY, pp. 1-22.

Boyle, J., 2004. Comment: A comparison of two methods for estimating the organic matter content of sediments. Journal of Paleolimnology 31, 125-127.

Brandon, C., Woodruff, J.D., Lane, P., Donnelly, J.P., 2013. Constraining flooding conditions for prehistoric hurricanes from resultant deposits preserved in Florida sinkholes. Geochemistry Geophysics Geosystems 14, 2993-3008.

Brinkmann, R., Reeder, P.P., 1994. The influence of sea-level change and geologic structure on cave development in west-central Florida. Physical Geography 15, 52-61.

Brown, A.L., Martin, J.B., Screaton, E.J., Ezell, J.E., Spellman, P., Gulley, J., 2014. Bank storage in karst aquifers: The impact of temporary intrusion of river water on carbonate dissolution and trace metal mobility. Chemical Geology 385, 56-69.

Carmichael, S.K., Carmichael, M.J., Strom, A., Johnson, K.W., Roble, L.A., Gao, Y., BRA, S.L., 2013. Sustained Anthropogenic Impact in Carter Saltpeter Cave, Carter County, Tennessee and the Potential Effects On Manganese Cycling. Journal of Cave and Karst Studies 75, 189.

Chen, C.S., 1965. The regional lithostatigraphic analysis of Paleocene and Eocene rocks of Florida.

Collins, S.V., Reinhardt, E.G., Rissolo, D., Chatters, J.C., Nava Blank, A., Luna Erreguerena, P., 2015a. Reconstructing water level in Hoyo Negro, Quintana Roo, Mexico, implications for early Paleoamerican and faunal access. Quaternary Science Reviews 438, 124-134.

Collins, S.V., Reinhardt, E.G., Werner, C.L., Le Maillot, C., Devos, F., Rissolo, D., 2015b. Late Holocene mangrove development and onset of sedimentation in the Yax Chen cave system (Ox Bel $\mathrm{Ha}$ ) Yucatan Mexico: implications for using cave sediments as a sea-level indicator. Palaeogeography, Palaeoclimatology, Palaeoecology 438, 124-134.

Cooke, C.W., 1939. Scenery of Florida interpreted by a geologist. Bulletin 17, Florida Geological Survey, Tallahassee, FL.

Cooke, C.W., 1945. Geology of Florida. Bulletin 37, The Florida Geological Survey, Tallahassee, FL.

Davison, W., 1993. Iron and manganese in lakes. Earth-Science Reviews 34, 119-163.

de Vitre, R., Davison, W., 1993. Manganese Particles in Freshwater. In: J. Buffle, H.P. van Leeuwin (Eds.), Environmental Particles. Lewis Publishers, Boca Raton, FL, pp. 317-352.

Dean, W.E., 1974. Loss on Ignition as a method for estimating organic and carbonate content in sediments: reproducibility and comparability of results. Journal of Paleolimnology 25, 101-110.

Delcourt, P.A., 1980. Goshen Springs: late Quaternary vegetation record for southern Alabama. Ecology, 371-386. 
Denomee, K.C., Bentley, S.J., Droxler, A.W., 2014. Climatic control on hurricane patterns: a 1200-y nearannual record from Lighthouse Reef, Belize. Scientific Reports 4, 7.

Deschamps, P., Durand, N., Bard, E., Hamelin, B., Camoin, G., Thomas, A.L., Henderson, G.M., Okuna, J., Yokoyama, Y., 2012. Ice-sheet collapse and sea-level rise at the Bølling warming 14,600 years ago. Nature 483, 559-564.

Dodson, J., 2013. FINAL REPORT Nutrient TMDL for Jackson Blue Spring and Merritts Mill Pond (WBIDs $180 Z$ and 180A). Florida Department of Environmental Protection, Division of Environmental Assessment and Restoration, Bureau of Watershed Restoration, Northwest DistrictApalachicola-Chipola Basin, Tallahassee.

Dufresne, D.P., Drake, D.R., 1999. Regional groundwater flow model construction and wellfield site selection in a karst area, Lake City, Florida. Engineering Geology 52, 129-139.

Fairbanks, R.G., 1989. A 17,000-year glacio-eustatic sea level record: influence of glacial melting rates on the Younger Dryas even and deep-ocean circulation. Nature 342, 637-642.

Fawcett, T., Faber, J., Kabbekodu, S., McClune, F., Rafaja, D., 2005. PDF-4+ 2005 (Database), Microstructure Analysis in Materials Science. International Centre for Diffraction Data, Newtown Square, PA, USA

Filley, T.R., Freeman, K.H., Bianchi, T.S., Colarusso, L.A., Hatcher, P.G., 2001. An isotopic biogeochemical assessment of shifts in organic matter input to Holocene sediments from Mud Lake, Florida. Organic Geochemistry 32, 1153-1167.

Florea, L.J., Stinson, C.L., Brewer, J., Fowler, R., Kearns, B.J., Greco, A.M., 2011. Iron oxide and calcite associated with Leptothrix sp. biofilms within an estavelle in the Upper Floridian Aquifer. International Journal of Speleology 40, 205-219.

Florea, L.J., Vacher, H.L., Donahue, B., Naar, D., 2007. Quaternary cave levels in peninsular Florida. Quaternary Science Reviews 26, 1344-1361.

Ford, D., Williams, P., 1989. Karst Geomorphology and Hydrology. Unwin Hyman, London.

Fornós, J., Ginés, A., Gracia, F., Merino, A., Gomez-Pujol, L., Bover, P., 2014. Cave deposits and sedimentary processes in Cova des Pas de Vallgornera (Mallorca, Western Mediterranean). International Journal of Speleology 43, 159-175.

Fornós, J.J., Ginés, J., Gràcia, F., 2009. Present-day sedimentary facies in the coastal karst caves of Mallorca island (western Mediterranean). Journal of Cave and Karst Studies 71, 86-99.

Fornós, J.J., Ginés, J., Gràcia, F., Merino, A., Gómez-Pujol, L., Bover, P., 2014. Cave deposits and sedimentary processes in Cova des Pas de Vallgornera (Mallorca, Western Mediterrean). International Journal of Speleology 43, 159-174.

Frierdich, A.J., Catalano, J.G., 2012. Distribution and speciation of trace elements in iron and manganese oxide cave deposits. Geochimica Cosmochimica Acta 91, 240-253.

Frydenbourg, R., 2006. Water Quality Study of the Ichetucknee River, Florida Department of Environmental Protection, Tallahassee, FL.

Gabriel, J.J., 2009. Late Holocene (3500 yBP) salinity changes and their climatic implications as recorded in an anchialine cave system, Ox Bel Ha, Yucatan, Mexico. MSc Thesis, McMaster University, 95 pp.

Gascoyne, M., Benjamin, G.J., Schwarcz, H.P., Ford, D.C., 1979. Sea-level lowering during the Illinoian Glaciation: evidence from a Bahama "Blue Hole". Science 205, 806-808.

Gázquez, F., Calaforra, J.M., Forti, P., 2011. Black Mn-Fe crusts as markers of abrupt paleoenvironmental changes in El Soplao Cave (Canabria, Spain). International Journal of Speleology 40, 163-169.

Ghiorse, W.C., Ehlich, H.I., 1992. Microbial biomineralization of iron and manganease. Catena Supplement 21, 75-99. 
Green, R.C., Williams, C.P., Paul, D.T., Kromhout, C., Scott, T.M., 2009. Geomorphology, springs, and karst features of the eastern portion of the USGS Ocala $30 \times 60$ minute quadrangle, NorthCentral Florida, Open-File Map. Florida Geological Survey, pp. Plate 3.

Grimm, E.C., Jacobson, G.L., Watts, W.A., Hansen, B.C.S., Maasch, K.A., 1993. A 50,000-year record of climate oscillations from Florida and its temporal correlation with the Heinrich events. Science 261, 198-200.

Gulley, J., Martin, J., Spellman, P., Moore, P., Screaton, E., 2014. Influence of partial confinement and Holocene river formation on groundwater flow and dissolution in the Florida carbonate platform. Hydrological Processes 28, 705-717.

Gulley, J.D., Martin, J.B., Moore, P.J., Murphy, J., 2013. Formation of phreatic caves in an eogenetic karst aquifer by $\mathrm{CO} 2$ enrichment at lower water tables and subsequent flooding by sea level rise. Earth Surface Processes and Landforms 38, 1210-1224.

Gulley, J.D., Martin, J.B., Screaton, E.J., Moore, P.J., 2011. River reversals into karst springs: A model for cave enlargement in eogenetic karst aquifers. Geological Society of America Bulletin 123, 457467.

Heiri, O., Lotter, A.F., Lemcke, G., 2001. Loss on ignition as a method for estimating organic and carbonate content in sediments: reproducibility and comparability of results. Journal of Paleolimnology 25, 101-110.

Hill, C.A., 1982. Origin of black deposits in caves. National Speleological Society Bulletin 44, 15-19. Jin, J., Zimmerman, A.R., Moore, P.J., Martin, J.B., 2014. Organic and inorganic carbon dynamics in a karst aquifer: Sante Fe River Sink-Rise System. Journal of Geophysical Research: Biogeosciences 119, 340-357.

Keating, B., 1985. Submersible observations on the flanks of Johnston Island (Central Pacific Ocean), Proceedings of the Fifth International Coral Reef Congress, Tahiti, pp. 413-418.

Kurz, M.J., Martin, J.B., Cohen, M.J., Hensley, R.T., 2015. Diffusion and seepage-driven element fluxes from the hyporheic zone of a karst river. Freshwater Science 34, 206-221.

Lane, P., Donnelly, J.P., Woodruff, J.D., Hawkes, A.D., 2011. A decadally-resolved paleohurricane record archived in the late Holocene sediments of a Florida sinkhole. Marine Geology 287, 14-30.

Larsen, E., Mangerud, J., 1989. Marine caves: on-off signals for glaciations. Quaternary International 3/4, 13-19.

Lazano, R.P., Rossi, C., 2012. Exceptional preservation of Mn-oxidizing microbes in cave stromatolies (El Soplao, Spain). Sedimentary Geology 255-256, 42-55.

Lehner, B., Grill, G., 2013. Global river hydrography and network routing: baseline data and new approaches to study the world's large river systems. Hydrological Processes 27, 2171-2186.

Lind, C., Hem, J., Roberson, C., 1987. Reaction products of manganese-bearing waters. Chemical Quality of Water and the Hydrological Cycle, 273-301.

Manolache, E., Onac, B.P., 2000. Geomicrobiology of black sediments in Vantului Cave (Romania): preliminary results. Cave and Karst Science 27, 109-112.

Martin, H.W., Harris, W.G., 1992. Mineralogy of clay sediments in three phreatic aves of the Suwanee River Basin. National Speleological Society Bulletin 54, 69-76.

Martin, J.B., Dean, R.W., 2001. Exchange of water between conduits and matrix in the Floridian aquifer. Chemical Geology 179, 145-165.

Martin, S.T., 2005. Precipitation and dissolution of iron and manganese oxides. Environmental Catalysis, 61-81.

Milliken, K., Anderson, J.B., Rodriguez, A.B., 2008. A new composite Holocene sea-level curve for the northern Gulf of Mexico. Geological Society of America Special Papers 443, 1-11.

Moore, W., 1955. Geology of Jackson County, Florida. 
Northup, D.E., Barns, S.M., Yu, L.E., Spilde, M.N., Schelble, R.T., Dano, K.E., Crossey, L.J., Connolly, C.A., Boston, P.J., Natvig, D.O., 2003. Diverse microbial communities inhabiting ferromanganese deposits in Lechuguilla and Spider Caves. Environmental Microbiology 5, 1071-1086.

Onac, B.P., Fornós, J., Merino, A., Ginés, J., Diehl, J., 2014. Linking mineral deposits to speleogenetic processes in Cova des Pas de Vallgornera (Mallorca, Spain). International Journal of Speleology $43,4$.

Onac, B.P., Hutchinson, S.M., Geanta, A., Forray, F.L., Wynn, J.G., Giurgiu, A.M., Coroiu, I., 2015. A 2500yr late Holocene multi-proxy record of vegetation and hydrologic changes from a cave guanoclay sequence in SW Romania. Quaternary Research 83, 437-448.

Onac, B.P., Pedersen, R.B., Tysseland, M., 1997. Presence of rare-earth elements in black ferromanganese coatings from Vântului Cave (Romania). Journal of Caves and Karst Studies 59, 128-131.

Osterman, L., Twichell, D.C., Poore, R., 2009. Holocene evolution of Apalachicola Bay, Florida. GeoMarine Letters 29, 395-404.

Overpeck, J.T., Peterson, L.C., Kipp, N., Imbrie, J., Rind, D., 1989. Climate change in the circum-North Atlantic region during the last deglaciation. Nature 338, 553-557.

Oyen, C.W., Protell, R.W., 2001. Diversity and patterns of biostratigraphy of Cenozoic echinoderms from Florida. Paleogeography, Paleoclimatology, Paleoecology 166, 193-218.

Palmer, A.N., 2007. Cave Geology. Cave Books.

Peck, S.B., 1986. Bacterial deposition of iron and manganese oxides in North American caves. National Speleological Society Bulletin 48, 26-30.

Peltier, W.R., Fairbanks, R.G., 2006. Global glacial ice volume and Last Glacial Maximum duration from an extended Barbados sea level record. Quaternary Science Reviews 25, 3322-3337.

Polk, J.S., van Beynen, P.E., Asmerom, Y., Polyak, V., 2013. Reconstructing past climates using carbon isotopes from fulvic acids in cave sediments. Chemical Geology 360-361, 1-9.

Puri, H., 1964. Stratigraphy and zonation of the Ocala Group: Florida Geological Survey Bulletin 38, 248 p., and Vernon. RO.

Quillen, A.K., Gaiser, E.E., Grimm, E.C., 2013. Diatom-based paleolimnological reconstruction of regional climate and local land-use change from a protected sinkhole lake in southern Florida, USA. Journal of Paleolimnology 49, 15-30.

Randazzo, A.F., Kosters, M., Jones, D.S., Portell, R.W., 1990. Paleoecology of shallow-maine carbonates, middle Eocene of Peninsular Florida. Sedimentary Geology 66, 1-11.

Randazzo, A.F., Zachos, L.G., 1984. Classification and description of dolomitic fabrics of rocks from the Floridian aquifer, USA. Sedimentary Geology 37, 151-162.

Reimer, P.J., Bard, E., Bayliss, A., Beck, J.W., Blackwell, P.G., Ramsey, C.B., Buck, C.E., Cheng, H., Edwards, R.L., Friedrich, M., 2013. IntCal13 and Marine13 radiocarbon age calibration curves 0-50,000 years cal BP. Radiocarbon 55, 1869-1887.

Rhoades, R., Sinacori, M.N., 1941. Pattern of ground-water flow and solution. Journal of Geology 49, 785-794.

Rossi, C., Lozano, R.P., Isanta, N., Hellstrom, J., 2010. Manganese stromatolites in caves: El Soplao (Cantabria, Spain). Geology 38, 1119-1122.

Rupert, F.R., 1988. The geology of Wakulla Springs. Open File Report 22, Florida Geological Survey, Tallahassee, FL.

Rupert, F.R., 1991. Lithology and palynology of cave floor sediment cores from Wakulla Spring, Wakulla County, Florida. Open Flle Report 47, Tallahasse, Florida.

Ryan, W.B., Carbotte, S.M., Coplan, J.O., O'Hara, S., Melkonian, A., Arko, R., Weissel, R.A., Ferrini, V., Goodwillie, A., Nitsche, F., 2009. Global multi-resolution topography synthesis. Geochemistry, Geophysics, Geosystems 10. 
Schmidt, W., 1988. Florida Caverns State Park, Jackson County, Florida, Open File Report 23. Florida Geological Survey, Tallahassee, FL.

Shinn, E.A., Reich, C.D., Locker, S.D., Hine, A.C., 1996. A giant sediment trap in the Florida Keys. Journal of Coastal Research 12, 953-959.

Spencer, S.M., Lloyd, J.M., 1999. Mineral resources of Jackson County, Florida, Tallahassee, Florida. Spilde, M.N., Northup, D.E., Boston, P.J., 2006. Ferromanganese deposits in the caves of the Guadalupe Mountains, New Mexico Geological Society 57th Annual Fall Field Conference Guidebook. New Mexico Geological Society, pp. 344.

Splide, M.N., Northrup, D.E., Boston, P.J., 2006. Ferromanganese deposits in the caves of the Guadalupe Mountains. In: L. Land, V.W. Leuth, W. Raatz, P. Boston, D.L. Love (Eds.), New Mexico Geological Society 57th Annual Fall Field Conference Guidebook, pp. 161-165.

Springer, G.S., Kite, J.S., 1997. River derived slackwater sediments in caves along Cheat River, West Virgina. Geomorphology 18, 91-100.

Springer, G.S., Kite, J.S., Schmidt, V.A., 1997. Cave sedimentation, genesis, and erosional history in the Cheat River Canyon, West Virginia. Geological Society of America Bulletin 109, 542-532.

Streever, W.J., 1996. Energy economy hypothesis and the troglobitic crayfish Procambarus erythrops in Sim's Sink Cave, Florida. American Midland Naturalist 135, 357-366.

Survey, F.G., Scott, T.M., Anderson, D., 2001. Geologic map of the State of Florida. Florida Geological Survey.

Teeter, J.W., 1995. Holocene saline lake history, San Salvador Island, Bahamas. In: H.A. Curan, B. White (Eds.), Terrestrial and Shallow Marine Geology of the Bahamas and Bermuda. Geological Society of America Special Paper 300, pp. 117-124.

Teeter, J.W., Quick, T.J., 1990. Magnesium salinity relation in the saline late ostracode Cyprideis americana. Geology 18, 220-222.

Twichell, D., Edmiston, L., Andrews, B., Stevenson, W., Donoghue, J., Poore, R., Osterman, L., 2010. Geologic controls on the recent evolution of oyster reefs in Apalachicola Bay and St. George Sound, Florida. Estuarine, Coastal and Shelf Science 88, 385-394.

van Hengstum, P.J., Donnelly, J.P., Kingston, A.W., Williams, B.E., Scott, D.B., Reinhardt, E.G., Little, S.N., Patterson, W.P., 2015a. Low-frequency storminess signal at Bermuda linked to cooling events in the North Atlantic region. Paleoceanography 30, 52-76.

van Hengstum, P.J., Donnelly, J.P., Toomey, M.R., Albury, N.A., Lane, P., Kakuk, B., 2014. Heightened hurricane activity on the Little Bahama Bank from 1350 to 1650 AD. Continental Shelf Research 86, 103-115.

van Hengstum, P.J., Reinhardt, E.G., Beddows, P.A., Gabriel, J.J., 2010. Investigating linkages between Holocene paleoclimate and paleohydrogeology preserved in Mexican underwater cave sediments. Quaternary Science Reviews 29, 2788-2798.

van Hengstum, P.J., Richards, D.A., Onac, B.P., Dorale, J.A., 2015b. Coastal caves and sinkholes. In: I. Shennan, A.J. Long, B.P. Horton (Eds.), Handbook of Sea-level Research. John Wiley and Sons.

van Hengstum, P.J., Scott, D.B., Gröcke, D.R., Charette, M.A., 2011. Sea level controls sedimentation and environments in coastal caves and sinkholes. Marine Geology 286, 35-50.

Vinther, B.M., Clausen, H.B., Fisher, D., Koerner, R., Johnsen, S.J., Andersen, K.K., Dahl-Jensen, D., Rasmussen, S.O., Steffensen, J.P., Svensson, A., 2008. Synchronizing ice cores from the Renland and Agassiz ice caps to the Greenland Ice Core Chronology. Journal of Geophysical Research: Atmospheres (1984-2012) 113.

Watts, W.A., 1969. A pollen diagram from Mud Lake, Marion County, North-Central Florida. Geological Society of America Bulletin 80, 631-642.

Watts, W.A., 1980. The late Quaternary vegetation history of the southeastern United States. Annual Review of Ecology and Systematics, 387-409. 
Watts, W.A., Hansen, B.C., 1988. Environments of Florida in the late Wisconsin and Holocene. Wet site archaeology, 307-323.

Watts, W.A., Hansen, B.C.S., 1994. Pre-Holocene and Holocene pollen records of vegetation history from the Florida peninsula and their paleoclimatic implications. Palaeogeography, Palaeoclimatology, Palaeoecology 109, 163-176.

Watts, W.A., Hansen, B.C.S., Grimm, E.C., 1992. Camel Lake: A 40 000-yr record of vegetational and forest history from northwest Florida. Ecology, 1056-1066.

Watts, W.A., Stuiver, M., 1980. Late Wisconsin climate of northern Florida and the origin of species-rich deciduous forest. Science 210, 325-327.

White, W.A., 1970. The geomorphology of the Florida peninsula.

White, W.B., 2007. Cave sediments and paleoclimate. Journal of Cave and Karst Studies 69, 76-93.

White, W.B., Vito, C., Scheetz, B.E., 2009. The mineralogy and trace element chemistry of black manganese oxide deposits from caves. Journal of Cave and Karst Studies 71, 136-143.

Wickert, A.D., Mitrovica, J.X., Williams, C., Anderson, R.S., 2013. Gradual demise of a thin southern Laurentide ice sheet recorded by Mississippi drainage. Nature 502, 668-671.

Wright, E.E., Hine, A.C., Goodbred, S.L., Locker, S.D., 2005. The effect of sea-level and climate change on the development of a mixed siliciclastic-carbonate, deltaic coastline: Suwanee River, Florida, USA. Journal of Sedimentary Research 75, 621-635.

Wurster, C.M., Patterson, W.P., McFarlane, D.A., Wassenaar, L.I., Hobson, K.A., Beavan-Athfield, N., Bird, M.I., 2008. Stable carbon and hydrogen isotopes from bat guano in the Grand Canyon, USA, reveal Younger Dryas and 8.2 ka events. Geology 36, 683-686.

Yamamoto, N., Kitamura, A., Irino, T., Kase, T., Ohashi, S., 2010. Climatic and hydrologic variability in the East China Sea during the last 7000 years based on oxygen isotopic records of the submarine caverniculous micro-bivalve Carditella iejimensis. Global Planetary Change 72, 131-140. 
Fig. 1: Map of the major watersheds, streams, deltas, and major geomorphic districts in northern Florida,

935 USA. Hole in the Wall (HITW) Cave and Twin Cave are located along the surficial stream Merrit's Mill

936 Pond (yellow star). Base maps, streams, and the borders of six major drainage basins are modified from

937 multi-resolution topographic (Ryan et al., 2009) and hydrographic databases (Lehner and Grill, 2013), and plotted using GeoMapApp software (http://www.geomapapp.org). Differentiation of confined, semiconfined, and unconfined Floridian aquifers (solid greyscale) is based on a map created by Kurz et al. (2015), as modified from Frydenbourg (2006). The interior border delineating where the upper Florida aquifer is confined (darkest grey) is locally known as the Cody Scarp. Borders of highly karstified geomorphologic districts (constrained by purple, red and yellow dashed lines) are derived from a map by Green et al. (2009). Springs and lakes that have been utilized in paleoclimate, hydrologic, and geologic studies that are referenced herein (yellow circles) include: Goshen Springs (Delcourt, 1980; Grimm et al., 1993), Camel Lake (Watts et al., 1992), Wakulla Springs (Rupert, 1988; 1991), Mud Lake (Watts, 1969), Madison Blue Spring (Brown et al., 2014), Ginnie Springs (Gulley et al., 2013), Sheelar Lake (Watts, 1980), and Thornton's Cave (Florea et al., 2011).

Fig. 2: (A) Topographic profile from the Gulf of Mexico to the study site (red line). A framework for deglacial sea-level rise is provided by relative sea-level change in the gulf of Mexico in green (Milliken et al., 2008), and blue data points are far-field coral-based sea-level index points (Peltier and Fairbanks, 2006). (B) Detailed cross section through the Meritts Mill Pond stream channel (red line). (C) Landsat image of the study site, with the magnitude 1 spring (Jackson Blue) in the top right. Both topographic profiles were generated using multi-resolution topographic data in (Ryan et al., 2009) GeoMapApp software.

Fig. 3: Original cave surveys (top panel, after original by Sheck Exley) denoting core locations, along with idealized cave cross section with core depths (lower panel) from HITW Cave (A) and Twin Cave (B). Black bars denote original sediment column before compression occurred during coring (not recovered length, Table 1). Blue (Yellow) circles denote cores that reached (did not reach) bedrock. Note: 'Sediment bypass' down Chimney 1 and/or the Skiles Passage likely precluded deposition of organic matter pulses

Fig. 4: Lithologic variability (core logs and photographs), bulk organic matter (wt. \%), coarse sediment fraction $\left(D_{>63 \mu \mathrm{m}}\right)$, location of $X R D$ and ${ }^{14} \mathrm{C}$ samples in all of the recovered cores. 
distribution) are from increased concentration of fossil invertebrates that have eroded out of the host carbonate. See Fig. 4 for symbols.

972 Fig. 6: A) Photographs from HITW-C1 depicting sediment typical of Units 1-6. B, C) Photographs from

973 TWIN-C5 and TWIN-C1 (respectively) that depict the heterogeneity of Unit 5 sediment. D) Well-sorted,

974 coarse quartz sand from Unit 6 in TWIN-C2. E) Poorly-sorted, coarse-grained Unit 1 from TWIN-C3. F)

975 Unit-2B coarse-grained carbonate sand from HITW-C4 that is well-sorted unlike most Unit 2B sediment.

976 G) Poorly-sorted carbonate sand in manganese-rich mud from HITW-C2 that is typical of Unit 4B.

Fig. 7: XRD results from representative sedimentary units 1-5 (Fig. 3, 4) in HITW Cave and Twin Cave. Reference peaks for minerals are identified below (stick graphs; (Fawcett et al., 2005) Fawcett, Faber,

980 Kabbekodu, McClune, \& Rafaja, 2005).

Fig. 8: Comparison of cave sedimentation to global climate variability over the last 20,000 years. $\delta^{18} \mathrm{O}$ isotopic curve from Greenland Ice Cores in Eastern Greenland (Vinther et al., 2008) and important global climate events (Fairbanks, 1989; Deschamps et al., 2012). Initiation of modern surficial hydrographic networks in Florida is indicated by flooding of Camel lake by water table rise (Watts et al., 1992), extension of the eastern lob of the Apalachicola River bayhead delta (Osterman et al., 2009), increase in regional precipitation at 5000 yr BP based on Sheelar Lake, Goshen Springs, and Little Salt Spring (Delcourt, 1980; Watts and Stuiver, 1980; Watts and Hansen, 1988; Alverez Zarikian et al., 2005), potential activation of surficial hydrology in the Suwaneee River drainage basin (Gulley et al., 2013) at $\sim 7900$ cal yr BP (Milliken et al., 2008). Stratigraphic emplacement of the three primary depositional styles

991 in Hole in the Wall Cave (HITW) and Twin Cave is based on available radiocarbon dates and general and 992 stratigraphic architecture.

Table 1: Summary of coring locations and sediment recovery from Hole in the Wall Cave and Twin Cave $(\mathrm{N} / \mathrm{R}=$ Not recorded $)$.

Table 2: Primary textural and mineralogical characteristics of recovered sedimentary units.

Table 3: Radiocarbon results on core samples from Hole in the Wall Cave and Twin Cave. 


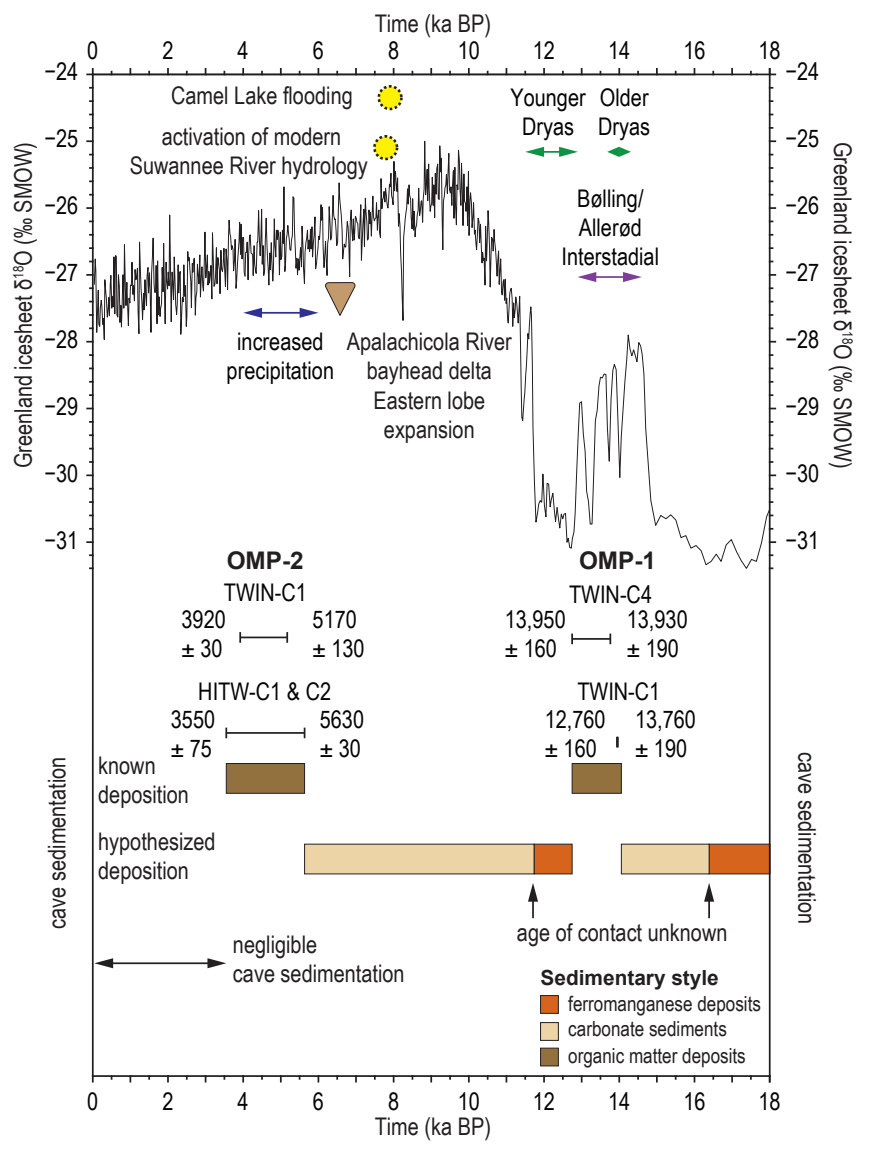

\section{Graphical Abstract (for review)}

兽

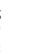

.

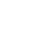




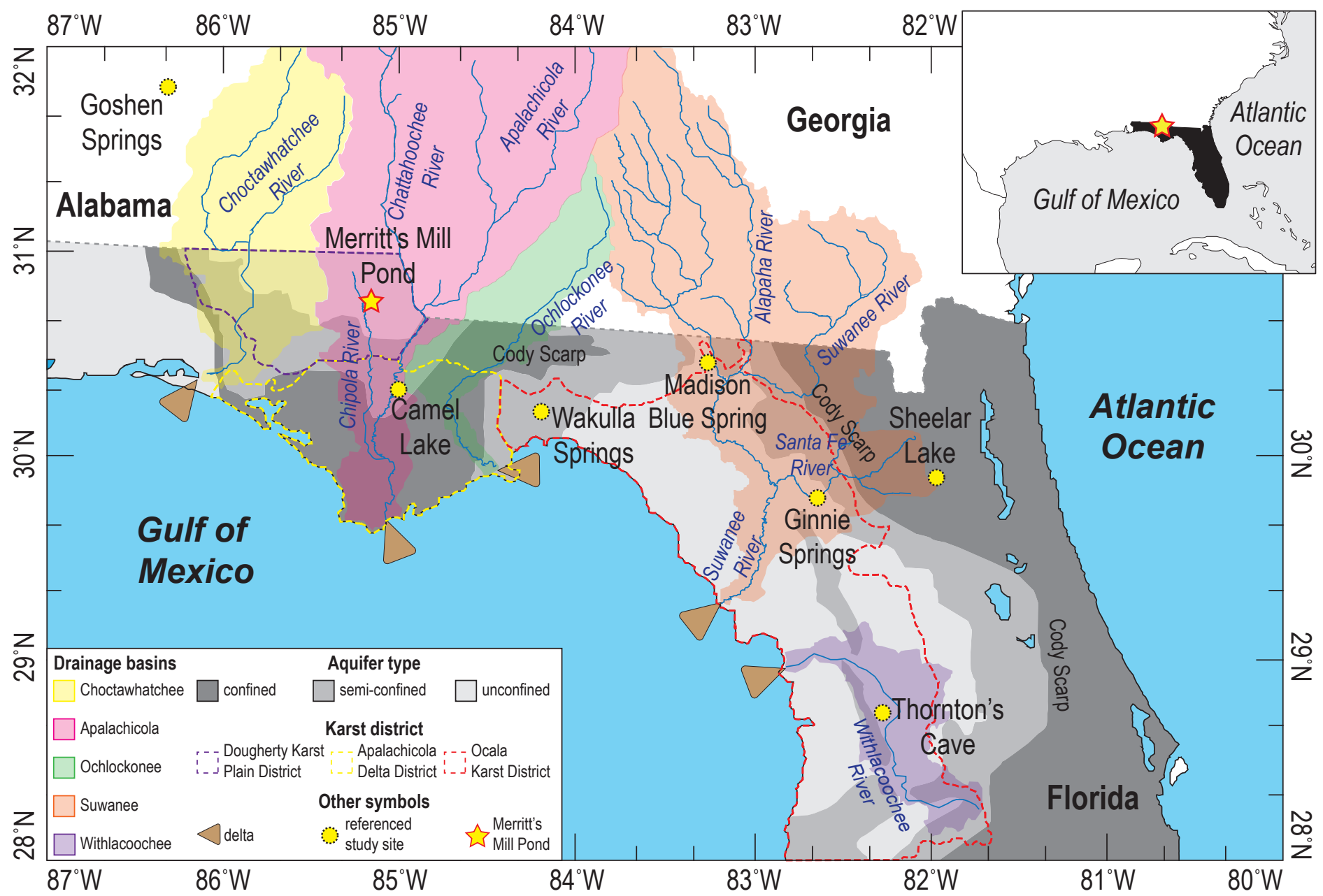



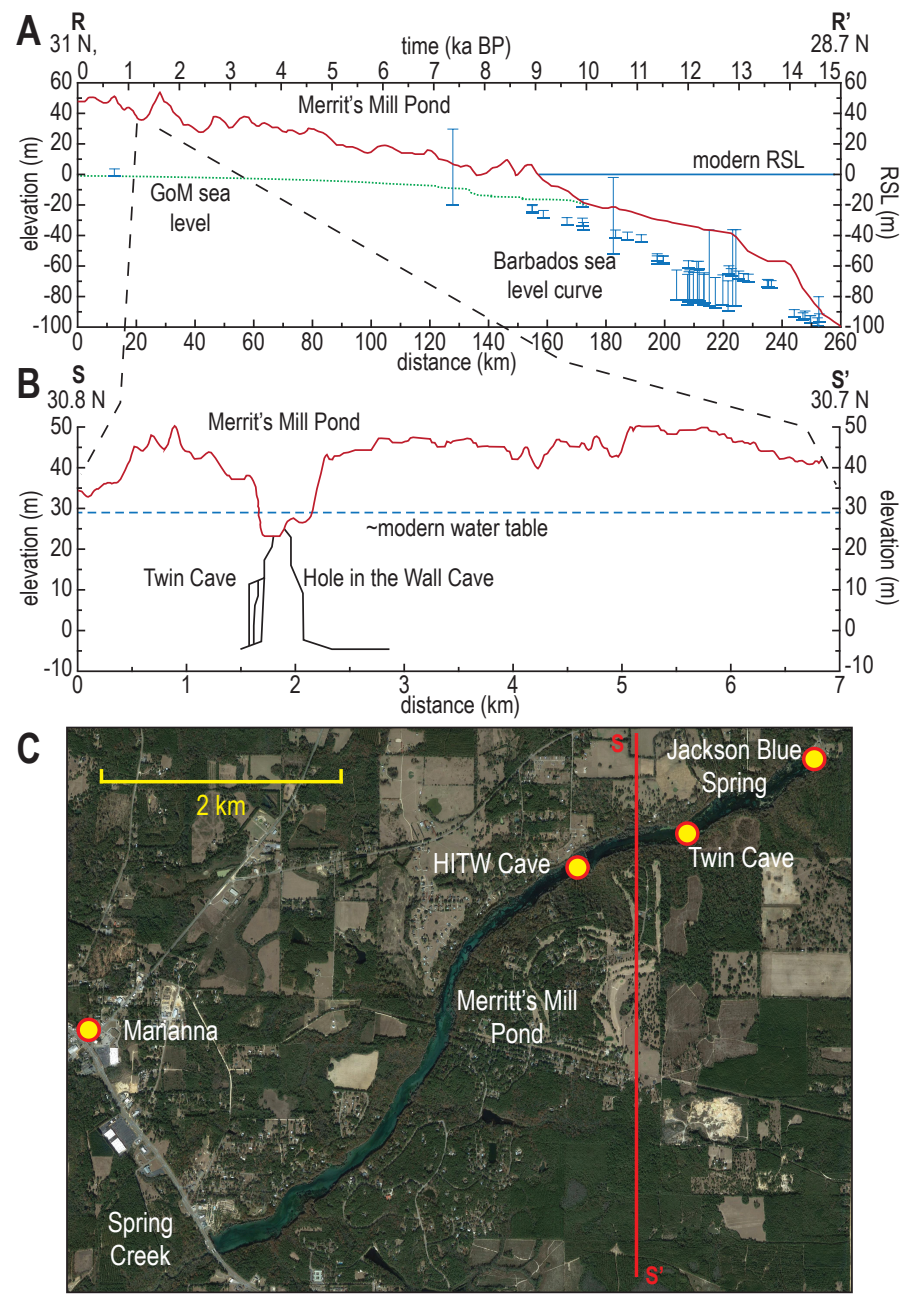

Figure 2 

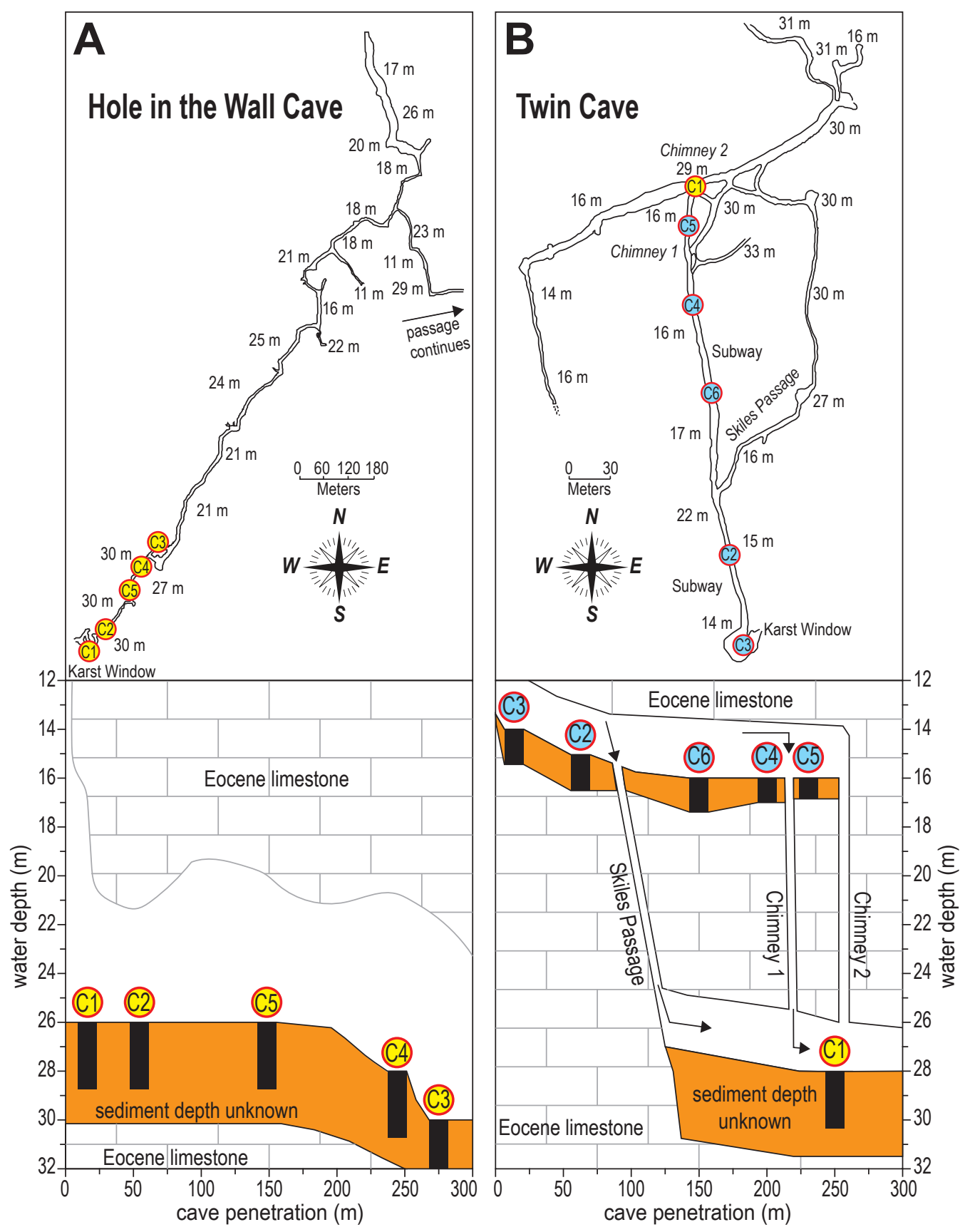


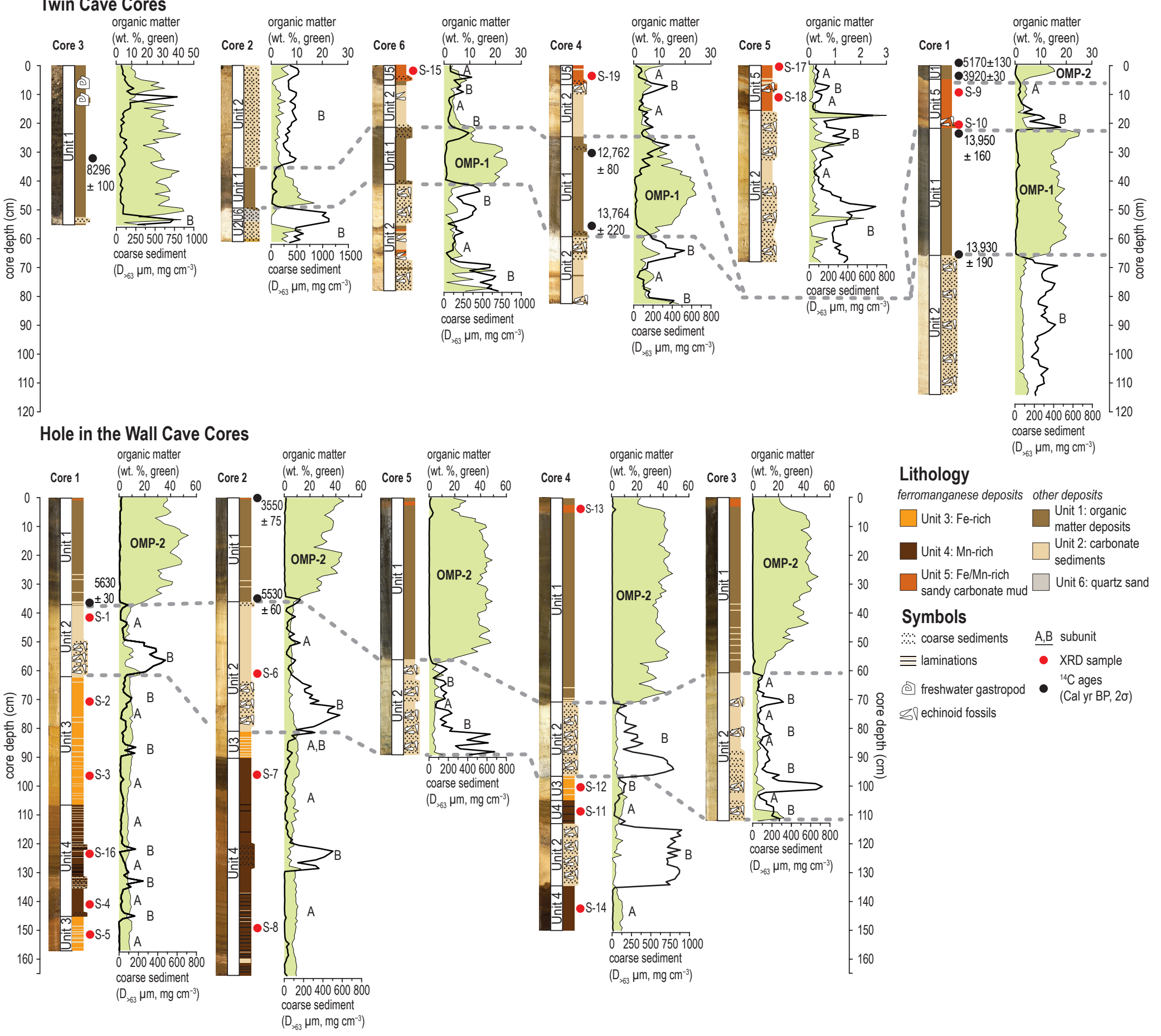


Figure 5

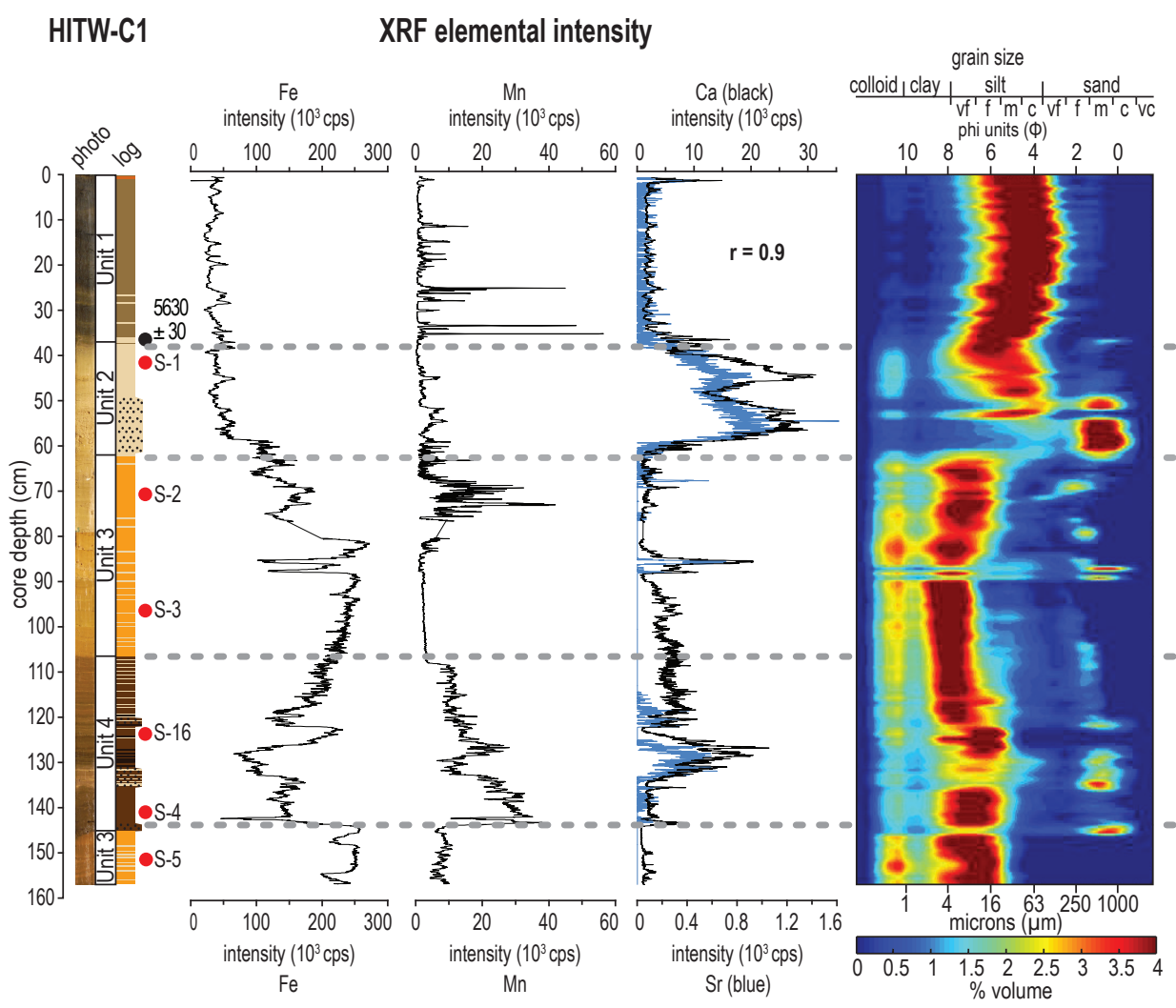

\section{Textural Analysis}

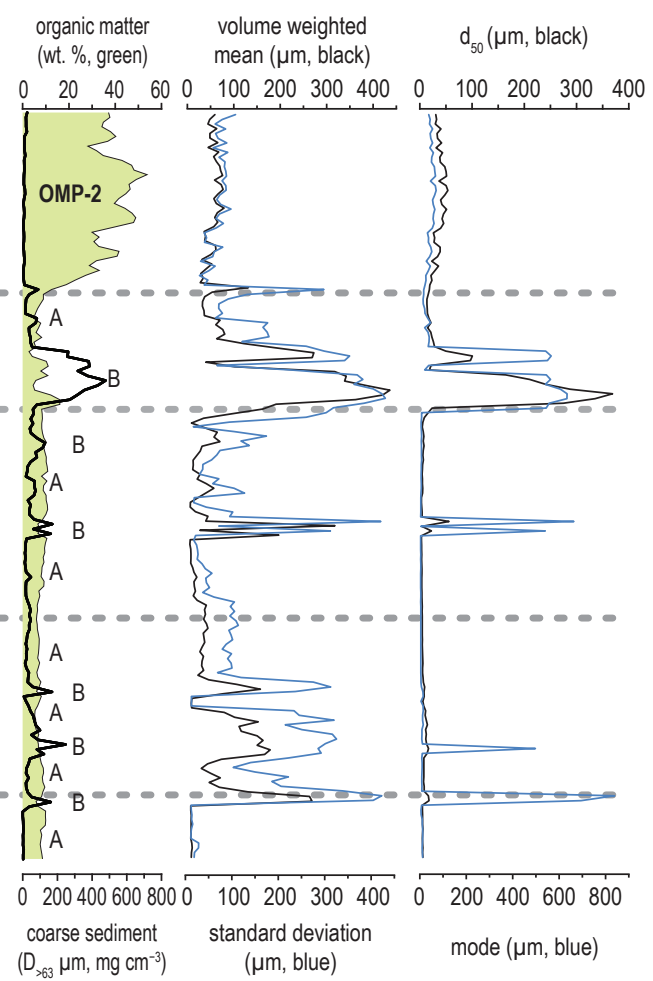



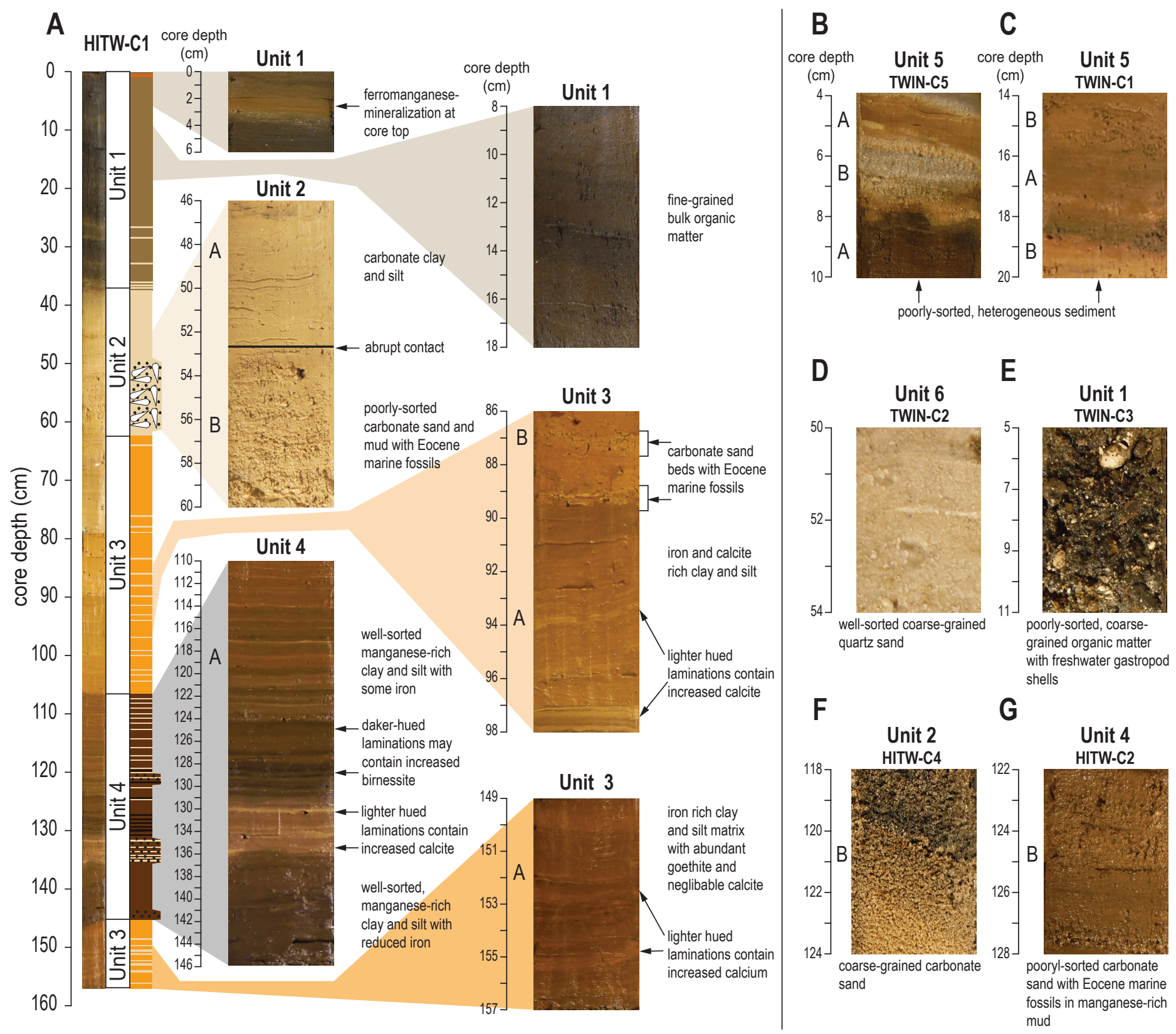
Figure 7
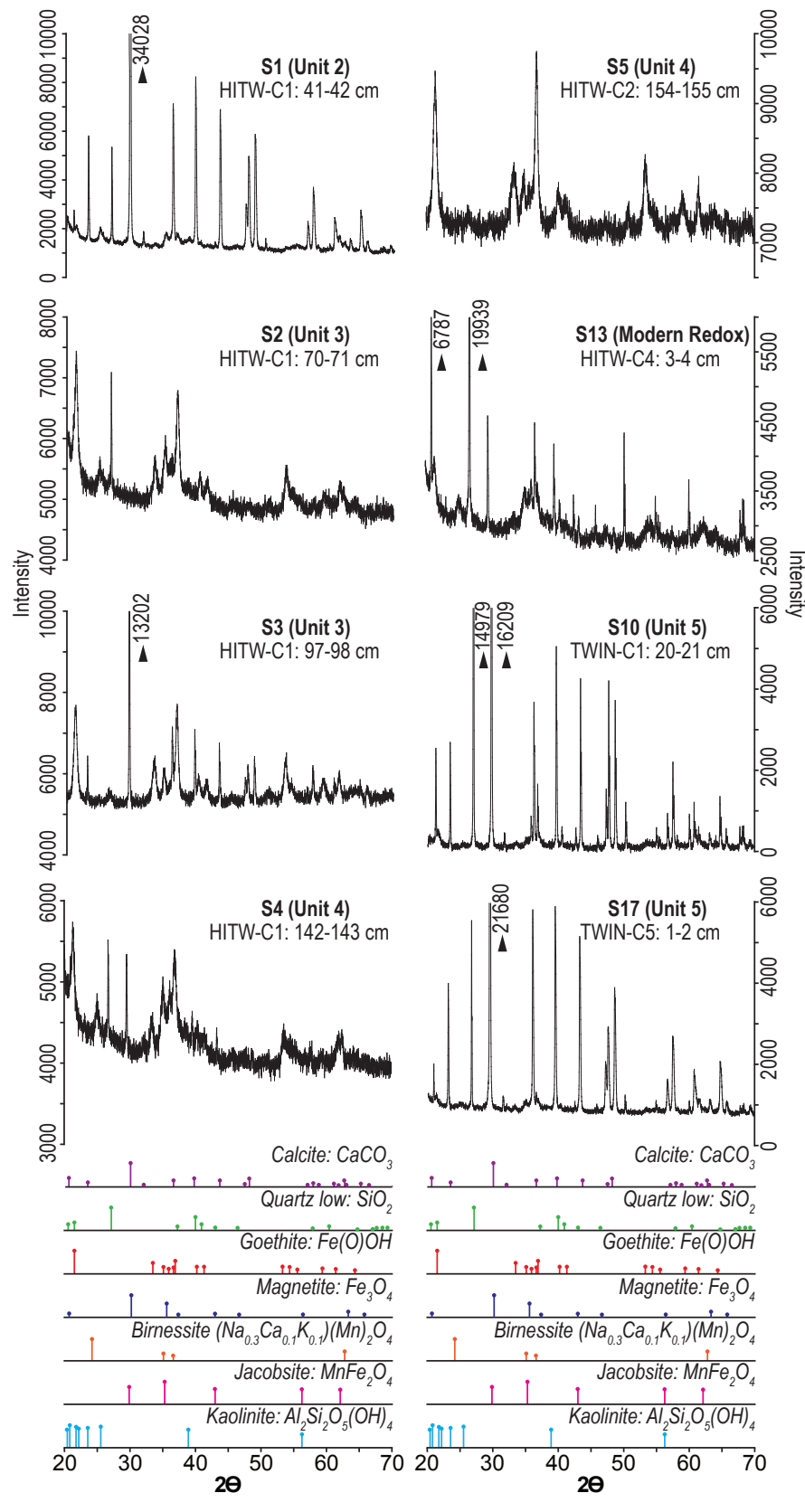

\section{高} 列 列 
Figure 8

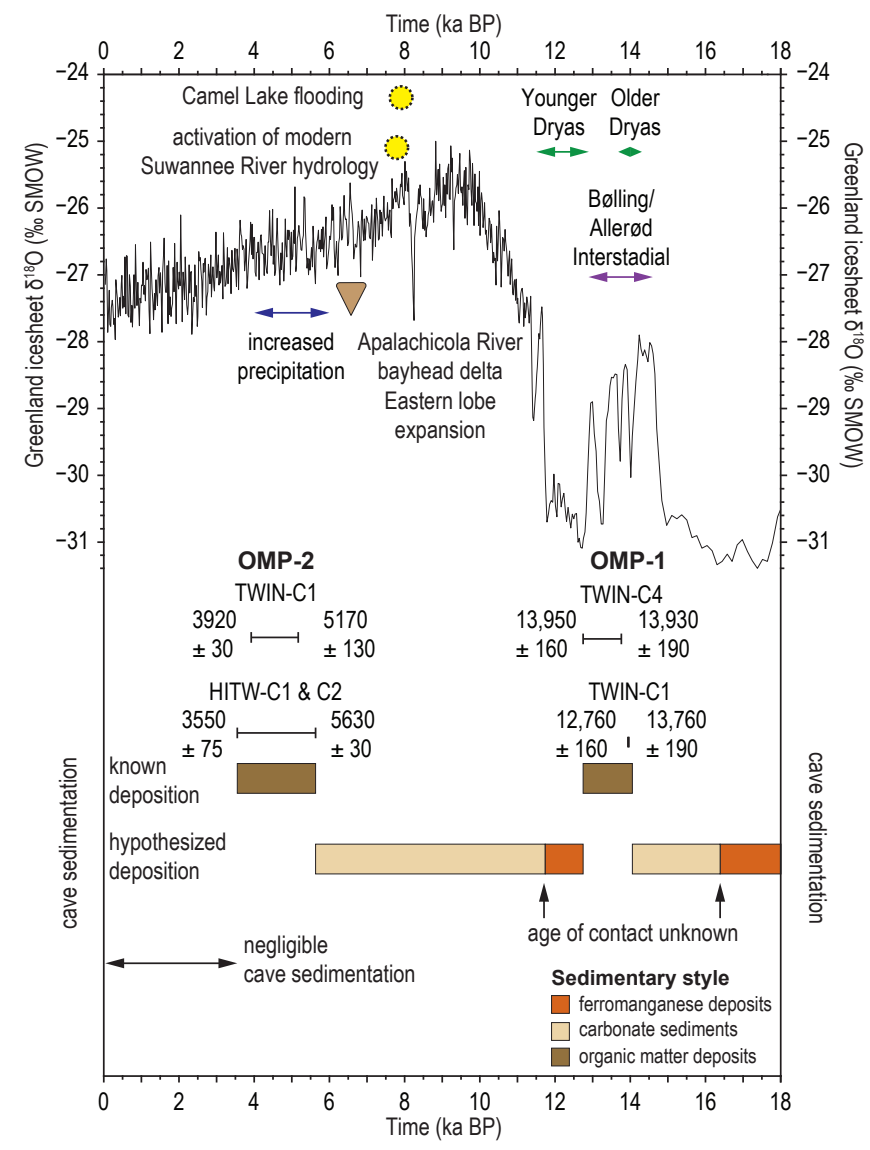


Table 1

\begin{tabular}{llllll}
\hline Core & $\begin{array}{l}\text { Horizontal cave } \\
\text { penetration }(\mathrm{m})\end{array}$ & Water depth $(\mathrm{m})$ & $\begin{array}{l}\text { Stratigraphic } \\
\text { column sampled } \\
(\mathbf{c m})\end{array}$ & $\begin{array}{l}\text { Compressed sediment } \\
\text { recovery }(\mathbf{c m})\end{array}$ & $\begin{array}{l}\text { Basement } \\
\text { reached }(\mathrm{Y} / \mathrm{N})\end{array}$ \\
\hline HITW-C1 & 15 & 26 & 240 & 157 & $\mathrm{~N}$ \\
HITW-C2 & 50 & 26 & 240 & 166 & $\mathrm{~N}$ \\
HITW-C3 & 274 & 30 & 150 & 111.5 & $\mathrm{~N}$ \\
HITW-C4 & 244 & 28 & 235 & 150.5 & $\mathrm{~N}$ \\
HITW-C5 & 137 & 26 & 240 & 88 & $\mathrm{~N}$ \\
TWIN-C1 & 250 & 28 & 220 & 113 & $\mathrm{~N}$ \\
TWIN-C2 & 60 & 15 & $* \mathrm{~N} / \mathrm{R}$ & 60 & $\mathrm{Y}$ \\
TWIN-C3 & 10 & 14 & 150 & 56.5 & $\mathrm{Y}$ \\
TWIN-C4 & 200 & 16 & 102 & 82 & $\mathrm{Y}$ \\
TWIN-C5 & 230 & 16 & 77 & 68 & $\mathrm{Y}$ \\
TWIN-C6 & 150 & 16 & 131 & 78 & $\mathrm{Y}$ \\
\hline
\end{tabular}


Table 2

\begin{tabular}{|c|c|c|c|c|c|c|}
\hline Unit & General texture & Grain size (HITW-C1) & Coarse sediment (>63 $\mu \mathrm{m}$ ) fraction & $\begin{array}{l}\text { Organic matter } \\
\text { content }\end{array}$ & Fossils & Munsell color \\
\hline \multirow[t]{2}{*}{1} & Bulk organic matter & $\begin{array}{l}5555 \pm 14 \mu \mathrm{m}(4-5 \phi) \\
n=37\end{array}$ & & $30 \% \pm 11$ & $\begin{array}{l}\text { Rare freshwater gastropod } \\
\text { shells and Eocene aged } \\
\text { Echinoid spines }\end{array}$ & \\
\hline & $\begin{array}{l}\text {-OMP-2: medium silt } \\
\text {-OMP-1: More in } \\
\text { organic matter in }\end{array}$ & & & & & \\
\hline
\end{tabular}




\begin{tabular}{|c|c|c|c|c|c|c|c|c|c|}
\hline Index No. & Lab number & Core & Sampled depth (cm) & Material dated & $\begin{array}{l}\text { Conventional }{ }^{14} \mathrm{C} \text { age } \\
\text { (BP) }\end{array}$ & $\delta^{13} \mathrm{C}(\%)$ & $\begin{array}{l}2 \sigma \text { calendar ages in yr BP } \\
\text { (probability) }\end{array}$ & $\begin{array}{l}1 \sigma \text { calendar ages in yr BP } \\
\text { (probability) }\end{array}$ & $\begin{array}{l}\text { Calibrated } 2 \sigma \text { age (yr } \\
\text { BP) }\end{array}$ \\
\hline 1 & OS-109437 & HITW-C1 & 36 to 37 & bulk organics & $4920 \pm 30$ & -29.1 & $\begin{array}{l}5596-5666(0.836) \\
5671-5714(0.164)\end{array}$ & $5605-5655$ (1) & $5630 \pm 30$ \\
\hline 2 & BETA-390615 & HITW-C2 & $0-1$ & bulk organics & $3320 \pm 30$ & -29.7 & $3470-3625$ (1) & $\begin{array}{l}3486-3536(0.547) \\
3549-3585(0.453)\end{array}$ & $3550 \pm 75$ \\
\hline 3 & OS-109438 & HITW-C2 & 34 to 35 & bulk organics & $4780 \pm 30$ & -29.15 & $5468-5590$ (1) & $\begin{array}{l}5479-5536(0.871) \\
5577-5585(0.129)\end{array}$ & $5530 \pm 60$ \\
\hline 4 & OS-109439 & TWIN-C1 & $4.5-5.5$ & bulk organics & $3560 \pm 25$ & -28.39 & $\begin{array}{l}3728-3748(0.042) \\
3764-3792(0.066) \\
3823-3926(0.879) \\
3949-3959(0.012)\end{array}$ & $3834-3889$ (1) & $3920 \pm 50$ \\
\hline 5 & BETA-390616 & TWIN-C1 & $0-1$ & bulk organics & $4490 \pm 30$ & -28.2 & $5038-5297$ (1) & $\begin{array}{l}5052-5077(0.152) \\
5104-5134(0.182) \\
5162-5195(0.204) \\
5206-5280(0.463)\end{array}$ & $5170 \pm 130$ \\
\hline 6 & OS-109440 & TWIN-C1 & $23-24$ & bulk organics & $12100 \pm 45$ & -31.37 & $13787-14105(1)$ & $\begin{array}{l}13853-13912(0.288) \\
13921-14045(0.712)\end{array}$ & $13950 \pm 160$ \\
\hline 7 & OS-109441 & TWIN-C1 & $66.5-67.5$ & bulk organics & $12000 \pm 50$ & -29.49 & 13738-14013 (1) & $\begin{array}{l}13764-13872(0.730) \\
13878-13927(0.270)\end{array}$ & $13930 \pm 190$ \\
\hline 8 & 15P/0494 & TWIN-C3 & $32-33$ & twig & $7500 \pm 60$ & $\mathrm{~N} / \mathrm{M}$ & 8198-8393 (1) & $\begin{array}{l}8215-8243(0.189) \\
8253-8255(0.013) \\
8303-8382(0.798)\end{array}$ & $8300 \pm 100$ \\
\hline 9 & 15OS/0492 & TWIN-C4 & $30-31$ & bulk organics & $10900 \pm 80$ & $\mathrm{~N} / \mathrm{M}$ & 12689-12836 (1) & 12704-12836 (1) & $12760 \pm 80$ \\
\hline 10 & $150 S / 0493$ & TWIN-C4 & $55-56$ & bulk organics & $11900 \pm 80$ & $\mathrm{~N} / \mathrm{M}$ & 13549-13978(1) & $13586-13783(1)$ & $13760 \pm 220$ \\
\hline
\end{tabular}

